\title{
Bilimin Doğası Alanında 2013 Yılından İtibaren Yayımlanmış Tezlerin Farklı Değişkenler Açısından İncelenmesi
}

\section{Hakan Şevki AYVACI*, Emine AKDEMIR**}

Öz: Bu çalışmanın amacı, bilimin doğası alanında 2013 yılı itibariyle yayımlanan çalışmaları incelemek, yapılan çalışmaların genel çerçevesini çizmek ve bu alandaki araştırmacılara yol göstermektir. Bu amaç doğrultusunda, 2013 yılından itibaren Yükseköğretim Kurumu Ulusal Tez merkezi'nde yayımlanmış olan ve bilimin doğası konusu üzerinde çalışılan 36 teze ulaşılmıştır. Araştırmada, analitik araştırma yöntemlerinden doküman analizi kullanılmıştır. Doküman analizi kapsamında tematik analiz gerçekleştirilerek, tezler; araştırma yılı ve türü, amaç, araştırma yaklaşımı, araştırma modeli, örneklem, veri toplama araçları, sonuçlar ve öneriler değişkenleri dikkate alınarak analiz edilmiştir. Her bir değişken için elde edilen veriler, frekans ve yüzde değerleri kullanılarak tablolar ve grafikler halinde sunulmuştur. Yapılan araştırma sonucunda ulaşılan tezlerin amaçları 17 başlık altında toplanmıştır. Araştırmaların modelleri ise 10 kategoride toplanmıştır. Bunun yanında örneklemler 5 ana başlık altında alt başlıkları da içerecek şekilde gruplandırılmıştır. Veri toplama araçları ise nitel veri toplama araçları 17 madde ve nicel veri toplama araçları ise 15 madde halinde sınıflandırılarak incelenmiştir. Bunlara ek olarak sonuçlar teması da incelenerek 26 madde şeklinde sunulmuştur. Son olarak da öneriler teması 20 başlık altında toparlanarak incelenmiştir. Araştırma sonunda, 2013 yılından bu yana bilimin doğası konusunda yapılan tezlerin yıllara göre dağılımında belirgin bir farklılık olmamakla birlikte, yüksek lisans tezlerinin sayısının daha fazla olduğu tespit edilmiştir. Yapılan çalışmalarda, araştırma yaklaşımı olarak karma yaklaşımın, araştırma modeli olarak deneysel araştırma modelinin, örneklem olarak öğretmen adaylarının ve öğrencilerin, veri toplama aracı olarak ise bilimin doğası ölçeği, mülakat ve gözlem tekniklerinin ağırlıklı olarak kullanıldığı sonucuna ulaşılmıştır. Ayrıca yapılan çalışmaların genellikle durum belirleme olarak ele alındığı, yeni ve farklı yönelimlere rastlanmadığı sonucuna ulaşılmıştır.

Anahtar Kelimeler: Bilimin doğası, doküman analizi, betimsel analiz

\footnotetext{
* Prof. Dr. Hakan Şevki AYVACI, Karadeniz Teknik Üniversitesi, Eğitim Fakültesi, Matematik ve Fen Bilimleri Eğitimi.hsayvaci@gmail.com

** Y. L. Öğrencisi Emine Akdemir, Karadeniz Teknik Üniversitesi, Eğitim Bilimleri Enstitüsü, Fen Bilgisi Eğitimi.emneakdmr@hotmail.com
}

$\begin{array}{lll}\text { Gönderim:30.03.2017 Kabul:05.06.2017 } & \text { Yayın:15.09.2017 }\end{array}$


An Examination of Theses in the Field of Nature of Science Published from 2013 in Terms of Different Variables

\begin{abstract}
The aim of this study is to examine the thesis published in the field of nature of science since 2013, to draw the general framework of the studies carried out and to lead the researchers in this area. In line with this aim, 36 theses have been reached which was published in the National Thesis Center of the Higher Education Institution from 2013 on the nature of science. In the research, document analysis was used as analytical research methods. Within the scope of the document analysis, thematic analyzes were carried out for the thesis in terms of research year and type, purpose, research approach, research model, sample, data collection tools, results and suggestions. The data obtained for each variable are presented in tables and graphs using frequency and percentage values. The objectives of theses reached as a result of this research are examined under 17 headings. The models of the researches are gathered in 10 categories. In addition, the samples are grouped under five main headings, including subheadings. Data collection tools were analyzed by classifying the qualitative data collection tools as 17 items and the quantitative data collection tools as 15 items. In addition to these, results themes are presented in the form of 26 articles. Finally, the proposals themes were examined by gathering in 20 titles. At the end of the research, it was determined that the number of master theses are more although there is no significant difference in the distribution of the theses made about the nature of science since the year of 2013. In the conducted studies, the results revealed that the mixed approach as the research approach, the experimental research model as the research model, the teacher candidates and the students as the sample, and the views on nature of science scale, interview and observation techniques as the data collection medium was the most used ones. In addition, the results indicated that the studies have generally been taken as determination of the situation and new and different orientations have not been found.
\end{abstract}

Keywords: Nature of science, document analysis, descriptive analysis 


\section{Giriş}

21.yüzyılda bilim ve teknoloji alanlarında gerçekleşen gelişmeler tarihteki gelişmelere göre toplumsal hayatın değişimine daha fazla etki etmiştir. $\mathrm{Bu}$ gelişmeler bilim ve teknolojinin insanın hayal gücünün çok ötesinde olduğunu göstermektedir. Bununla birlikte sosyal ve kültürel hayatın önemli bir parçası haline gelen bilim ve teknoloji; eğitim, ekonomi, politika ve kültür gibi alanlarla da bir etkileşim halindedir. Bu nedenle bireyin ve toplumun gelişmesi için bilim ve bilim öğretimine önem verilmesi gerekmektedir. Bu bağlamda bilim öğretiminin amacı, öğrencilerin bilimsel bilgiyi kullanarak okulda, gelecek yaşamlarında, meslek hayatlarında başarılı olmalarını sağlamaktır (Driver, Leach, Millar ve Scoot, 1996). Günümüzün gelişmiş toplumlarında bilime, bilimin işleyiş̧ine ve bilimin ortaya koyduğu fikirlere karşı olumlu tutuma sahip, temel bilimsel bilgileri bilen, bilimin ortaya koyduğu bilgi ve tartışmalara eleştirel yaklaşabilen yani bilimsel okuryazar olan bireylere ihtiyaç vardır (Ayvac1, 2007).

Bilimsel bilgiye ulaşmada önemli olan bilim öğretimi tüm insanları bilim okuryazarı olarak yetiştirmeyi, bilim insanlarının elde ettiği teori ve kuramları nasıl ortaya koyduklarını ve bunları hangi yolları kullandıklarını kısacası bilimin nasıl yapıldığını anlamalarını sağlar. Herkes tarafından kabul edilmiş ortak bir tanıma sahip olmayan bilimsel okuryazarlık veya fen okuryazarlığı terimini literatürdeki tanımlara göre genel bir çerçeveye toplamak mümkündür. Kısacası bilimin doğasını bilen, bilimsel düşünebilme becerisine sahip olan bireyler bilimsel okuryazardır (Collette ve Chiapetta, 1984; Norris ve Philips, 2003; Weld, 2004). Bilimsel okuryazar bir bireyin sahip olması gereken en önemli özelliklerden biri bilim ve bilimin doğası hakkında anlamlı görüşlere sahip olmasıdır. Ayrıca bilimsel okuryazar olan bireylerin bilimin doğasını anlamaları gerekmektedir(Lederman, 1992, 2004,2007 ; Lederman ve Zeidler, 1987). 
Bilimin doğası kavramı, bilimin ne olduğunu ve nasıl işlev gösterdiğini, bilimsel bilginin nasıl üretildiğini, bilimin toplumu nasıl etkilediğini, bilimsel gelişmelerden toplumun nasıl etkilendiğini anlamaya çalışan geniş bir alandır. Bilim eğitimi programları ile öğrenciler özelde bilim eğitiminin ilk aşamalarını; genelde ise temel bilimsel okuryazarlık becerilerini kazanmaya çalışırlar (Driver ve diğ. 1996). Bununla birlikte bilimin doğasının öğretimi ile fen eğitiminde bilgiye ulaşmayı ve bu bilgiyi günlük hayatta kullanabilmeyi öğretmek amaçlanmaktadır. Bilim okuryazarlığının önemli unsurlarından biri olan bilimin doğasının öğretimi bu nedenle fen eğitiminin temel amaçlarından biri haline gelmiştir (MEB, 2005 ve 2013).

Gerçekleşen değişimler ve gelişimler beraberinde öğretim programlarında yer alan kazanımların değişmesinde etkili olsa da, bilimin doğası görüşlerini geliştirme öğretim programlarının başlıca hedeflerinden biri olmuştur (AAAS, 1990; NGSS, 2013; NRC, 1996; MEB, 2005, 2013). 2005 yılındaki MEB Fen ve Teknoloji Öğretim Programı'nda öğrencilerin fen ve teknoloji okuryazarı olarak yetiştirilmesi hedeflenmiştir. Fen ve teknoloji okuryazarı olan bir birey, bilimin ve bilimsel bilginin doğasını, temel fen kavramı, ilke, yasa ve kuramlarını anlayarak uygun şekillerde kullanarak fen, teknoloji, toplum ve çevre arasındaki etkileşimi anladığı ifade edilmektedir (MEB,2005).

2013 yılında yayımlanan İlk okul ve Orta okul Fen Bilimleri Dersi Öğretim Programı'nda; Fen ve Teknoloji dersinin adı Fen Bilimleri olarak değiştirilmiştir. Programın ve dersin vizyonu aynı kalarak tüm öğrencilerin fen bilimlerine ilişkin temel bilgilere ve doğal çevrenin keşfine yönelik bilimsel süreç becerilerine sahip; sosyal ve teknolojik değişim ve dönüşümlerin fen ve doğa ile olan ilişkisini kavrayabilen fen okuryazarı bireyler olarak yetiştirilmesi amaçlanmıştır. Bununla birlikte öğrencilerin kazanacağı davranış alanları bilgi, beceri, duyuş ve fen-teknoloji-toplum-çevre olarak dört alana ayrılarak bilimin doğasına fenteknoloji-toplum-çevre alanı altında yer verilmiştir(MEB, 2013). 
Fen bilimleri eğitiminin daha etkili bir şekilde verilmesinde öğretim programları oldukça önemlidir. Bilim ve teknoloji alanlarındaki gelişmelerin fen eğitimi programlarına yansıtılması gerekmektedir. Fen alanındaki öğretim programlarının geliştirilmesinde bilimdeki yenilikler ve eğitim alanındaki yönelimler dikkate alınmaktadır (Wiles, Bondi, 1989; Onstein, Hunkins, 1993; Ayas, 1995; Ünal, Çoştu ve Karataş, 2004).

Buraya kadar olan kısımda bilimsel okuryazarlık ve bilimin doğasının ne olduğu; fen öğretim programları içerisindeki öneminden söz edilmiştir. Son y1llarda bilimin doğası tüm dünyada olduğu gibi ülkemizde de fen eğitiminde ilgi duyulan bir alan haline gelmiştir( Bala, 2013). İnce ve Özgelen (2015), bilimin doğası alanında yaptı̆̆ı çalışmada son 10 yılda yapılan çalışmaları farklı değişkenler açısından incelemiştir. Yürütülen çalışmada SSCI/SCI dergilerinde yayınlanmış 127 makale doküman analizi yöntemi ile incelenmiştir. Elde edilen veriler yayın yılı, yaklaşım, desen, örneklem ve veri toplama araçları olmak üzere 5 değişken açısından içerik analizine tabi tutulmuştur. Benzer şekilde Erdaş, Doğan ve İrez ( 2016) bilimin doğasıyla ilgili 1998-2012 yılları arasında Türkiye'de yapılan çalışmaların değerlendirmesini yaptıkları çalışmada 134 çalışmayı doküman analizi yöntemi ile konu, örneklem, metot ve sonuçları açısından incelemiştir. Yürütülen bu çalışmada incelenecek çalışmalar için benzer şekilde doküman analizi kullanılmakla birlikte incelemenin daha geniş çaplı değişkenler ile yürütülmesi esas alınmıştır. Bilimin doğası konusunda öğrencilerin, öğretmenlerin görüşleri gibi alanlarda yapılan çalışmalara göre içerik analizi çalışmalarının az olması ve yapılacak araştırmanın bilimin doğası üzerine yapılan çalışmaların genel çerçevesini çizmesi ve bu alandaki çalışmaların yetersiz olduğu alanların belirlenip ileriki araştırmacılara yol göstermesi amacıyla 2013 yılı MEB Fen Bilimleri Yeni Öğretim Programı'ndan itibaren yayımlanan çalışmaların incelenmesi hedeflenmiştir. 


\section{Yöntem}

Araştırmanın Modeli. Nitel yaklaşıma dayalı yürütülen çalışmanın modeli doküman analizidir. Yapılan çalışmada 2013 yılından itibaren yayımlanmış olan bilimin doğası ile ilgili yürütülmüş olan tezler incelenmiştir. Tezlerle ilgili elde edilen bilgiler oluşturulan temalara göre kodlanarak incelemiştir.

Araştırmanın Örneklemi. 2013 yılından itibaren Yükseköğretim Kurulu Ulusal Tez Merkezi'nde yayımlanan ve 'bilimin doğası' konusu üzerinde çalışılan tezler örneklem olarak ele alınmıştır. Bu kapsamda toplam 49 teze ulaşılmıştır. Elde edilen yayınlardan toplamda 30 tezin erişime açık olduğu geri kalan tezlerin kısıtlı olduğu görülmüştür. Yayınların kısıtlı olması üzerine tez yazarları ile iletişime geçilerek 6 araştırmacıdan olumlu dönüt alınabilmiştir. Sonuç olarak 2015 yılında hazırlanmış 10, 2014 yılında hazırlanmış 14 ve 2013 yılında hazırlanmış 12 tez olmak üzere toplam 36 teze ulaşılabilmiştir.

Ek 1'de 2013 yılından itibaren bilimin doğası alanında yayımlanmış olan tezlerden araştırma örnekleminde yer alan tezler; araştırma yılı, araştırma türü, araştırmacı, araştırma adı ve araştırmanın yayınlandığı üniversite/ enstitü başlıkları altında gösterilmiştir.

Araştırma İşlem Süreci. Araştırma sürecinde elde edilen tezlerin incelenmesi için 8 tema; araştırma yılı ve türü, araştırmanın amacı, araştırma yaklaşımı, araştırma modeli, örneklem, veri toplama araçları, sonuçlar ve öneriler şeklinde belirlenmiştir. 2013 yılından itibaren yayımlanmış olan bilimin doğası konulu tezler belirlenen 8 tema açısından incelenerek frekans dağılımlarına ve yüzdelik dağılımlarına yer verilmiştir.

Verilerin Analizi. Çalışma nitel yaklaşıma göre yapılmıştır. Doküman analizi yöntemi ile toplanan veriler içerik analizine tabi tutulmuştur. İçerik analizi gelecekte yapılacak 
çalışmalar ve uygulamalar da önemli bir role sahip olmasının yanında araştırılan konunun yaygınlaştırılmasında da etkilidir (Suri ve Clarke, 2009). Bu çalışmada elde edilen veriler içerik analizlerinden biri olan tematik analiz desenine göre incelenmiştir. Tematik analiz araştırma yapılan konunun çeşitli değişkenler açısından temalar oluşturularak incelenip eğilimlerin ve araştırma sonuçlarının tanımlayıcı bir boyutta değerlendirilmesini içeren sistematik bir analizdir (Çalık ve Sözbilir, 2014; Yıldırım ve Şimşek, 2011). Tematik analiz ile yürütülen araştırmada temalar anlamlılık analizi ile araştırma yılı ve türü, araştırmanın amacı, araştırma yaklaşımı, araştırma modeli, örneklem, veri toplama araçları, sonuçlar ve öneriler olarak oluşturulmuştur.

\section{Bulgular}

Bu bölümde, bilimin doğası konusunda 2013 yılından itibaren yayımlanmış olan 36 tez araştırma yılı ve türü, araştırma amacı, araştırma yaklaşımı, araştırma modeli, örneklem, veri toplama araçları, sonuç ve öneriler temaları olmak üzere toplam 8 tema kapsamında incelenmiştir.

Bilimin Doğası Hakkında 2013 Yılından İtibaren Yayımlanmış Tezlerin Araştırma Yıllarına ve Araştırma Türlerine Göre İncelenmesi

Tablo 1'de 2013 yılından itibaren bilimin doğası alanında yayımlanmış olan tezlerin araştırma yılı ve türü kapsamında yıllara göre sayıları ve yüzdelik değerleri yer almaktadır. 
Tablo 1. Bilimin Doğası Hakkında 2013 Yılından İtibaren Yayımlanmış Tezlerin Araştırma Yıllarına ve Araştırma Türlerine Göre Dağılımları

\begin{tabular}{|c|c|c|c|c|c|c|}
\hline \multirow{3}{*}{ Araştırma Yılı } & \multirow{3}{*}{$\mathbf{f}$} & \multirow{3}{*}{$\%$} & \multicolumn{4}{|c|}{ Araştırma Türü } \\
\hline & & & \multicolumn{2}{|c|}{ Yüksek Lisans } & \multicolumn{2}{|c|}{ Doktora } \\
\hline & & & $\mathbf{f}$ & $\%$ & $\mathbf{f}$ & $\%$ \\
\hline 2013 & 12 & 33,3 & 7 & 19,4 & 5 & 13,8 \\
\hline 2014 & 14 & 38,8 & 7 & 19,4 & 7 & 19,4 \\
\hline 2015 & 10 & 27,7 & 7 & 19,4 & 3 & 8,3 \\
\hline Toplam & 36 & 100 & 21 & $\mathbf{5 8 , 3}$ & 15 & 41,7 \\
\hline
\end{tabular}

Tablo 1 incelendiğinde 2013 yılında yayımlanmış 12 tezin 7'sinin yüksek lisans, 5'inin ise doktora türünde olduğu;-2014 yılında yayımlanmış olan 14 tezin 7'sinin yüksek lisans,-7'sinin doktora türünde yapılmış olduğu;-2015 yılında ise yayımlanmış olan toplam 10 tezden 7'sinin yüksek lisans, 3'ünün doktora türünde yapıldığ görülmektedir. Genel olarak bakıldığında 2013 yılından itibaren bilimin doğası alanında yayımlanmış tezlerin \% $\% 2$ 'sinin yüksek lisans,\%58'inin doktora türünde yürütüldüğü belirlenmiștir. 2013 yılından itibaren bilimin doğası alanında yayımlanmış olan tez sayıları arasında yıllara göre belirgin bir fark gözlenmezken, araştırma türü açısından doktora alanında yapılan çalışmalara 2015 yılında daha az yer verildiği görülmektedir.

Bilimin Doğası Hakkında 2013 Yılından İtibaren Yayımlanmış Tezlerin Araştırma Amaçlarına Göre İncelenmesi

Tablo 2'de 2013 yılından itibaren bilimin doğası alanında yayımlanmış olan 36 tez amaç teması bakımından incelenerek frekans ve yüzdelik dağılımları gösterilmiştir. 
Tablo 2. Bilimin Doğası Hakkında 2013 Yılından İtibaren Yayımlanmış Tezlerin Araştırma Amaçlarına Göre Dă̆ılımı

\begin{tabular}{|c|c|c|c|}
\hline & Amaç & f & $\%$ \\
\hline 1 & Bilimin doğasına yönelik bakış açıları(görüşleri) araştırmak. & 15 & 42 \\
\hline 2 & Bilimin doğasına yönelik anlayışların gelişimini incelemek. & 3 & 8,4 \\
\hline 3 & $\begin{array}{l}\text { Bilimin doğasına yönelik bakış açıları(görüşleri)belirlemek ve bilimin } \\
\text { doğasının öğretimi. }\end{array}$ & 2 & 5,5 \\
\hline 4 & $\begin{array}{l}\text { Bilimin doğasına yönelik görüssler, eleştirel düşünme becerileri ve } \\
\text { akademik başarıyı incelemek. }\end{array}$ & 2 & 5,5 \\
\hline 5 & Bilimsel okuryazarlık boyutlarını geliştirmek. & 2 & 5,5 \\
\hline 6 & $\begin{array}{l}\text { Kavramsal anlama, bilimsel süreç becerileri ve bilimin doğasına yönelik } \\
\text { görüşleri incelemek. }\end{array}$ & 1 & 2,7 \\
\hline 7 & Bilimin doğası öğretiminin amaçları ve niteliğinin değişimini belirlemek. & 1 & 2,7 \\
\hline 8 & Bilimin doğasına yönelik görüşler ve epistemolojik inançları incelemek. & 1 & 2,7 \\
\hline 9 & MEB dokümanları( ders kitabı) bilimin doğası açısından incelemek. & 1 & 2,7 \\
\hline 10 & $\begin{array}{l}\text { Fiziğin doğası hakkındaki temel görüşleri, akademik başarı ve kalıcılığı } \\
\text { incelemek. }\end{array}$ & 1 & 2,7 \\
\hline 11 & $\begin{array}{l}\text { Bilimin doğasına yönelik görüşler, epistemolojik inançlar ve bilimsel süreç } \\
\text { becerilerini incelemek. }\end{array}$ & 1 & 2,7 \\
\hline 12 & Bilimin sosyal temellerini göstermek. & 1 & 2,7 \\
\hline 13 & Biyolojik okuryazarlığı göstermek. & 1 & 2,7 \\
\hline 14 & Öz yeterlik algıları, çevre bilgileri ve çevresel tutumları incelemek. & 1 & 2,7 \\
\hline 15 & $\begin{array}{l}\text { Sosyobilimsel konularda akıl yürütme ile bilimsel bilginin doğasını anlama } \\
\text { arasındaki ilişkiyi belirlemek. }\end{array}$ & 1 & 2,7 \\
\hline 16 & $\begin{array}{l}\text { Öz inceleme yoluyla bilimin doğası öğretimi uygulamalarının nasıl } \\
\text { gerçekleştiğini keşfetmek. }\end{array}$ & 1 & 2,7 \\
\hline \multirow[t]{2}{*}{17} & Bilimin nasıl ilerlediğine yanıt aramak. & 1 & 2,7 \\
\hline & Toplam & 36 & 100 \\
\hline
\end{tabular}

Tablo 2 incelendiğinde 2013 yılından itibaren bilimin doğası alanında yayımlanmış olan tezlerin \%42'sinde 'Bilimin doğasına yönelik bakış açıları(görüşleri) araştırmak.' amacının en yüksek frekansa sahip olduğu görülmektedir. Bununla birlikte incelenen tezlerin 
\%8,4'ünde 'Bilimin doğasına yönelik anlayışların gelişimini incelemek.', \%5,5'inde 'Bilimin doğasına yönelik bakış açıları(görüşleri)belirlemek ve bilimin doğasının öğretimi.', \%5,5'inde 'Bilimin doğasına yönelik görüşler, eleştirel düşünme becerileri ve akademik başarıyı incelemek.' ve \%5,5'inde 'Bilimsel okuryazarlık boyutlarını geliştirmek.' amaç olarak belirtildiği görülmektedir.

\section{Bilimin Doğası Hakkında 2013 Yılından İtibaren Yayımlanmış Tezlerin}

\section{Araştırma Yaklaşımlarına Göre İncelenmesi}

Tablo 3'de 2013 yılından itibaren bilimin doğası alanında yayımlanmış olan tezlerin yürütüldüğü yaklaşımların yıllara göre dağılımları ve yüzde olarak gösterimlerine yer verilmiştir.

Tablo 3. Bilimin Doğası Hakkında 2013 Yılından İtibaren Yayımlanmış Tezlerin Araştırma Yaklaşımlarına Göre Dağılımı

\begin{tabular}{|c|c|c|c|c|c|c|c|}
\hline \multirow[t]{2}{*}{ Araştırma Yılı } & \multicolumn{2}{|c|}{$\begin{array}{l}\text { Karma } \\
\text { Yaklaşım }\end{array}$} & \multicolumn{2}{|c|}{ Nicel Yaklaşım } & \multicolumn{2}{|c|}{ Nitel Yaklaşım } & \multirow[t]{2}{*}{ Toplam } \\
\hline & f & $\%$ & f & $\%$ & f & $\%$ & \\
\hline 2013 & 6 & 50 & 4 & 33,3 & 2 & 16,7 & 12 \\
\hline 2014 & 7 & 50 & 2 & 14,2 & 5 & 35,7 & 14 \\
\hline 2015 & 6 & 60 & 1 & 10 & 3 & 30 & 10 \\
\hline Toplam & 19 & 52,7 & 7 & 19,4 & 10 & 27,7 & 36 \\
\hline
\end{tabular}

Tablo 3 incelendiğinde 36 tezden 19'unun karma yaklaşım esasında yürütüldüğ̈̈,36 tezin 10 'nun nitel yaklaşım ve 36 tezden 7'sinin nicel yaklaşıma dayalı olarak yürütüldüğü görülmüştür.-2013 yılında bilimin doğası konusunda yayımlanmış olan tezlerin \%50'sinin karma, \%33,3'ünün nicel ve \%16,7'sinin nitel yaklaşımla yapıldığı;-2014 yılında bilimin doğası konusunda yayımlanmış olan tezlerin \%50'sinin karma,\%14,2'sinin nicel ve \%35,7’sinin nitel yaklaşımla yürütüldüğü;-2015 yılında bilimin doğası konusunda 
yayımlanmış olan tezlerin \%60 karma,\%10'unun nicel ve \%30'unun nitel yaklaşım esasına dayandırılarak yürütüldüğü belirlenmiştir. Genel olarak bakıldığında 2013 yılından itibaren yayımlanmış bilimin doğası alanındaki tezlerdeki çalışmaların \%52,7'sinin karma yaklaşım, \%19,4'ünün nicel yaklaşım ve \%27,7'sinin ise nitel yaklaşım esasında yapıldı̆̆ 1 görülmektedir.

\section{Bilimin Doğası Hakkında 2013 Yılından İtibaren Yayımlanmış Tezlerin}

\section{Araştırma Modellerine Göre İncelenmesi}

Tablo 4'te 2013 yılından itibaren bilimin doğası alanında yayımlanmış olan tezlerin yürütülmesinde kullanılan araştırma modellerinin yıllara göre dağılımları ve yüzde olarak gösterimlerine yer verilmiştir.

Tablo 4. Bilimin Doğası Hakkında 2013 Yılından İtibaren Yayımlanmış Tezlerin Araştırma Modellerine Göre Dă̆glımı

\begin{tabular}{|c|c|c|c|}
\hline Araştırmalar & Araştırma modeli & $\mathbf{f}$ & $\%$ \\
\hline \multirow[t]{2}{*}{ Betimsel Araştırmalar } & M1. Örnek olay (Özel Durum) & 6 & 16,7 \\
\hline & M2. Tarama & 5 & 14 \\
\hline \multirow{3}{*}{ Yorumlayıcı Araştırmalar } & M3. Eylem araştırması & 1 & 2,7 \\
\hline & M4. Olgu bilim & 3 & 8,2 \\
\hline & M5. Etnografik çalışma & 1 & 2,7 \\
\hline \multirow{3}{*}{ Analitik Araştırmalar } & M6. Doküman analizi & 1 & 2,7 \\
\hline & M7. Yarı deneysel & 7 & 19,5 \\
\hline & M8. Deneysel & 6 & 16,7 \\
\hline \multirow[t]{2}{*}{ Diğer } & M9. Karma & 5 & 14 \\
\hline & M10. Öz-inceleme & 1 & 2,7 \\
\hline Toplam & & 36 & 100 \\
\hline
\end{tabular}

Tablo 5 incelendiğinde 2013 yılından itibaren bilimin doğası konusunda yürütülmüş olan tezlerde \%19,5 oranı ile en çok kullanılan araştırma modelinin analitik araştırmalardan yarı deneysel model olduğu; bununla birlikte \%16,7'lik değerle analitik araştırmalardan deneysel modelin ve \%16,7'lik değerle betimsel araştırmalardan özel durum modelinin çok 
tercih edildiği görülmektedir. Bunlara ek olarak yapılmış olan tezlerin \%14'ü betimsel araştırmalardan tarama modeli ile, \%14'ü karma model ile , \%8,2'si yorumlayıcı araştırmalardan olgu bilim modeli ile yapılmıştır.

Bilimin Doğası Hakkında 2013 Yılından İtibaren Yayımlanmış Tezlerin Araştırma Örneklemi Seçimine Göre İncelenmesi

Tablo 5'te 2013 yılından itibaren bilimin doğası alanında yayımlanmış olan tezlerin yürütülmesinde araştırma örneklemi seçiminin dağılımları ve yüzde olarak gösterimlerine yer verilmiştir.

Tablo 5. Bilimin Doğası Hakkında 2013 Yılından İtibaren Yayımlanmış Tezlerin Araştırma Örneklemi Seçimine Göre Dă̆ılımı

\begin{tabular}{|c|c|c|c|c|}
\hline Örneklem & & $\mathbf{f}$ & $\mathbf{f}$ & $\%$ \\
\hline \multirow{5}{*}{ Ö1 Öğretmen adayı } & Fen bilgisi öğretmen adayı & 7 & \multirow{5}{*}{15} & \multirow{5}{*}{41,6} \\
\hline & Sınıf öğretmen adayı & 3 & & \\
\hline & $\begin{array}{c}\text { Sosyal bilgiler öğretmen } \\
\text { adayı }\end{array}$ & 2 & & \\
\hline & Biyoloji öğretmen adayı & 2 & & \\
\hline & Kimya öğretmen adayı & 1 & & \\
\hline \multirow[t]{3}{*}{ Ö2 Öğrenci } & Okul öncesi & 1 & \multirow{3}{*}{14} & \multirow[t]{3}{*}{38,8} \\
\hline & Ortaokul & 12 & & \\
\hline & Lise & 1 & & \\
\hline \multirow[t]{2}{*}{ Ö3 Öğretmen } & Fen öğretmeni & 2 & \multirow[t]{2}{*}{3} & \multirow[t]{2}{*}{8,3} \\
\hline & Sinıf öğretmeni & 1 & & \\
\hline Ö4 Bilim insanı ve öğretmen & & & 1 & 2,7 \\
\hline Toplam & & & 33 & 91,4 \\
\hline
\end{tabular}

Tablo 5 incelendiğinde 2013 yılından itibaren bilimin doğası alanında yayımlanmış olan tezlerin örneklem seçiminde \%41,6'sının öğretmen adayları; \%38,8'inin öğrenciler olduğu görülmektedir. Öğretmen adayları üzerinde yürütülen 15 çalışmadan 7'sinde fen bilgisi öğretmen adayları üzerinde çalışıldığı; öğrenciler üzerinde yürütülen 14 çalışmanın 
12’sinin ortaokul düzeyinde öğrencilerle yapılmış olduğu belirlenmiştir. Ayrıca 2013 yılından itibaren yürütülmüş bilimin doğası konulu tezlerin \%8,3’ü öğretmenlerle, \%2,7’si ise bilim insanı ve öğretmen örneklemleri üzerinde yapılmıştır. Örneklem bulundurmadığı için 3 tez bu tema kapsamında incelenememiştir. İncelemeye dâhil edilemeyen çalışmalarda ders kitapları, öğretim programları gibi kaynaklar doküman analizi ile incelenmiştir. Ayrıca felsefe ve sosyoloji alanlarında yapılan açıklama niteliğinde çalışmalar da yer aldığı için örneklem belirtilememiştir.

\section{Bilimin Doğası Hakkında 2013 Yılından İtibaren Yayımlanmış Tezlerin Veri}

\section{Toplama Araçlarının Seçimine Göre İncelenmesi}

Tablo 6’te 2013 yılından itibaren bilimin doğası alanında yayımlanmış olan tezlerin yürütülmesinde kullanılan veri toplama araçlarının nitel ve nicel veri toplama araçları olarak dağılımları ve yüzdelik gösterimlerine yer verilmiştir.

Tablo 6. Bilimin Doğası Hakkında 2013 Yılından İtibaren Yayımlanmış Tezlerin Veri Toplama Araçlarının Seçimine Göre Dağılımı

\begin{tabular}{llcccccc}
\hline & $\begin{array}{l}\text { Nicel Veri Toplama } \\
\text { Araçları }\end{array}$ & f & \% & & $\begin{array}{l}\text { Nitel Veri } \\
\text { Toplama } \\
\text { Araçları }\end{array}$ & f & \% \\
\hline Nc1 & Bilimin doğası ölçeği & 27 & 54 & Nt1 & Görüşme & 20 & 40 \\
\hline Nc2 & Başarı testi & 5 & 10 & $\mathbf{N t 2}$ & Gözlem & 7 & 14 \\
Nc3 & Kavram testi & 4 & 8 & $\mathbf{N t 3}$ & Video kaydı & 4 & 8 \\
Nc4 & $\begin{array}{l}\text { Bilimsel süreç becerileri } \\
\text { ölçeği }\end{array}$ & 3 & 6 & $\mathbf{N t 4}$ & Ders planı & 3 & 6 \\
Nc5 & $\begin{array}{l}\text { Bilimsel epistemolojik } \\
\text { inançlar ölçeği }\end{array}$ & 1 & 2 & $\mathbf{N t 5}$ & $\begin{array}{l}\text { Araştırmacı } \\
\text { notları }\end{array}$ & 2 & 4 \\
Nc6 & Biyoteknoloji bilgi anketi & 1 & 2 & Nt6 & $\begin{array}{l}\text { Çalışma } \\
\text { yaprakları }\end{array}$ & 2 & 4 \\
\hline
\end{tabular}




\begin{tabular}{|c|c|c|c|c|c|c|c|}
\hline Ne7 & Çevresel tutum ölçeği & 1 & 2 & Nt7 & $\begin{array}{l}\text { İçerik sunum } \\
\text { formu }\end{array}$ & 2 & 4 \\
\hline Nc8 & Eleştirel düşünme testi & 1 & 2 & Nt8 & $\begin{array}{l}\text { Öğrenci } \\
\text { çalışmaları }\end{array}$ & 2 & 4 \\
\hline Nc9 & $\begin{array}{l}\text { Epistemolojik inançlar } \\
\text { ölçeği }\end{array}$ & 1 & 2 & Nt9 & $\begin{array}{l}\text { Öğretmen } \\
\text { dokümanları }\end{array}$ & 2 & 4 \\
\hline Ne10 & $\begin{array}{l}\text { Fen teknoloji toplum üzerine } \\
\text { görüşler anketi }\end{array}$ & 1 & 2 & Nt10 & Arkadaş görüşleri & 1 & 2 \\
\hline Ne11 & Fen tutum testi & 1 & 2 & Nt11 & Fotoğraflar & 1 & 2 \\
\hline Ne12 & Kelime ilişkilendirme testi & 1 & 2 & Nt12 & Günlük & 1 & 2 \\
\hline Ne13 & Kişisel bilgi formu & 1 & 2 & Nt13 & Günlük e-postalar & 1 & 2 \\
\hline Ne14 & Öz yeterlik algısı ölçeği & 1 & 2 & Nt14 & Kavram haritası & 1 & 2 \\
\hline \multirow[t]{4}{*}{ Nc15 } & $\begin{array}{l}\text { Sosyobilimsel konularla } \\
\text { ilgili } \\
\text { karar alma anketi }\end{array}$ & 1 & 2 & Nt15 & $\begin{array}{l}\text { Kisa hikâyelerin } \\
\text { dokümanları }\end{array}$ & 1 & 2 \\
\hline & & & & Nt16 & $\begin{array}{l}\text { Yansitma } \\
\text { formları }\end{array}$ & 1 & 2 \\
\hline & & & & Nt17 & Yaşam öyküleri & 1 & 2 \\
\hline & Toplam & 50 & 100 & & & 52 & 100 \\
\hline
\end{tabular}

Tablo 6 incelendiğinde 2013 yılından itibaren bilimin doğası konusunda yürütülmüş olan tezlerde en s1k kullanılan nicel veri toplama aracının \%54'lük oranla 'Bilimin doğası ölçeği’; nitel verilerin toplanmasında ise \% 40’lık oran ile en sık başvurulan veri toplama aracının 'Görüşme' olduğu görülmektedir. Ayrıca incelenen tezlerden elde edilen veriler sonucunda nicel verilerin toplanmasında \%10 'Başarı testi', \%8 'Kavram testi', \%6 'Bilimsel süreç becerileri ölçeği' ;nitel verilerin toplanmasında ise \%14 'Gözlem' , \%8 'Video Kaydı' ve \%6 'Ders planı’ veri toplama aracı olarak kullanılmıştır.

Bilimin Doğası Hakkında 2013 Yılından İtibaren Yayımlanmış Tezlerin Elde Ettiği Sonuçlara Göre İncelenmesi 
Tablo 7'de 2013 yılından itibaren bilimin doğası alanında yayımlanmış olan tezlerin yürütülmesinde ulaşılan sonuçlar genel maddeler halinde temalaştırılarak incelenen tezlerin sonuçlarının dağılımlarına ve yüzdelik gösterimlerine yer verilmiştir.

Tablo 7. Bilimin Doğası Hakkında 2013 Yılından İtibaren Yayımlanmış Tezlerin Elde Ettiği Sonuçlara Göre Dağılımı

\begin{tabular}{|c|c|c|c|}
\hline & Sonuçlar & $\mathbf{f}$ & $\%$ \\
\hline S1 & Çalışmanın bilimin doğası görüşlerini olumlu yönde etkilediği. & 7 & $\begin{array}{l}19, \\
6\end{array}$ \\
\hline S2 & $\begin{array}{l}\text { Öğretmen ve öğretmen adaylarının bilimin doğası ve içerik alan bilgisi } \\
\text { açısından yetersiz kaldıkları. }\end{array}$ & 4 & $\begin{array}{l}11, \\
2\end{array}$ \\
\hline S3 & $\begin{array}{l}\text { Sosyal bilgiler öğretmen adaylarının bilimsel okuryazarlık düzeyleri } \\
\text { araştırmanın amacına uygun olarak gelişim göstermesi. }\end{array}$ & 1 & 2,8 \\
\hline S4 & Bilimin toplumdan koparılamayacağı. & 1 & 2,8 \\
\hline S5 & Öz düzenlemenin bilimin doğası anlayışlarına olumlu katkı sağladığı. & 1 & 2,8 \\
\hline S6 & $\begin{array}{l}\text { Bilim insanları ile fen ve teknoloji öğretmenlerinin farklı bilimin doğası } \\
\text { görüşlerine sahip olduğu. }\end{array}$ & 1 & 2,8 \\
\hline S7 & $\begin{array}{l}\text { Öğretmen adaylarının uygun bilimin doğası bakış açılarına sahip olmadığı. } \\
\text { Cinsiyete göre farkın olmayıp; üniversitelere göre farkın olduğu. }\end{array}$ & 1 & 2,8 \\
\hline S8 & $\begin{array}{l}\text { Biyolojik okuryazarlıkta cinsiyete göre farkın olduğu; mezun olunan lise } \\
\text { türü, lisans sınıf düzeyi, akademik ortalama açısından farkın olmadığı. }\end{array}$ & 1 & 2,8 \\
\hline S9 & $\begin{array}{l}\text { Bilim öğretimindeki değisşimin Türkiye'deki ekonomik, siyasi değişim } \\
\text { süreçlerine denk düştüğü. }\end{array}$ & 1 & 2,8 \\
\hline S10 & $\begin{array}{l}\text { Biyoteknoloji etkinliklerinin 8.sınıf öğrencilerinin biyoteknoloji bilgilerini } \\
\text { ve bilimin doğası görüşlerini olumlu yönde etkilediği. }\end{array}$ & 1 & 2,8 \\
\hline S11 & $\begin{array}{l}\text { Ortak bilgi yapılandırma modeli ile 7. sınıf Fen ve Teknoloji dersi } \\
\text { ögrencilerin akademik başarılarını, kavramsal değişimlerini, fene karşı } \\
\text { tutumlarını, bilimin doğası ile ilgili bakış açlarını geliştirmede etkili } \\
\text { olduğu. }\end{array}$ & 1 & 2,8 \\
\hline S12 & $\begin{array}{l}\text { Argümantasyon temelli fen eğitiminin fen bilgisi öğretmen adaylarının } \\
\text { bilimin doğasına yönelik görüşlerinde ve epistemolojik inançlarında } \\
\text { gelişme olduğu. }\end{array}$ & 1 & 2,8 \\
\hline S13 & $\begin{array}{l}\text { 6. Sınıf öğrencilerinin eleştirel düşünme ile akademik başarı ve kavramsal } \\
\text { anlamaları arasında pozitif bir ilişkinin olduğu ve Ortak bilgi yapılandırma } \\
\text { modelinin öğrencilerin bilimin doğası konusunda görüşe sahip olmalarında } \\
\text { önemli ölçüde başarılı olduğu. }\end{array}$ & 1 & 2,8 \\
\hline S14 & $\begin{array}{l}\text { Modelleme sürecine dayalı fen eğitimi uygulamaları ile ortaokul } \\
\text { düzeyindeki öğrencilerin bilimin doğasına ilişkin görüşlerinin } \\
\text { geliştirilebildiği. }\end{array}$ & 1 & 2,8 \\
\hline S15 & Sosyal bilgiler öğretmen adaylarının bilimin doğasına bakış açılarının & 1 & 2,8 \\
\hline
\end{tabular}


geleneksel olup cinsiyete bağlı olmayıp; sınıf düzeyi arttıkça değişim gösterdiği.

S16 Bilim tarihi eğitiminin müfredat tabanlı eğitime göre daha başarılı olduğu. 12,8

S17 Öğretmen adaylarının genelinin bilimin doğasına yönelik çağdaş bir $\quad \begin{array}{lll}2,8 \\ 2\end{array}$ anlayışa sahip olmadığı ve cinsiyet değişkeninde kızların, üniversite değişkeninde vakıf üniversitelerinin, sınıf düzeyinde de dördüncü sınıfların diğer durumlara kıyasla bilimin doğası alanında daha çağdaş anlayışa sahip olduğu.

S18 Sınıf seviyesi artıkça kimya kitaplarında değinilen bilimin doğası $1 \quad 2,8$ boyutlarının sayısının azalmakta olduğu.

S19 Yaşam temelli öğretim ve öğrenme istasyonları yöntemi ile öğretimin $\quad 1 \quad 2,8$ fiziğin doğası ile ilgili anlamlı bir farklılığa sebep olmadığı .

S20 Fen Bilgisi öğretmenlerinin yüksek özyeterlik algısı ve çevresel tutuma $\quad 1 \quad 2,8$ sahip olmalarına rağmen orta düzeyde çevre bilgisine sahip oldukları.

S21 Bilimsel bilginin doğasını anlamanın sosyo-bilimsel konularda akıl $\quad 1 \quad 2,8$ yürütmeyi etkileme eğiliminde olduğu.

S22 Öğrencilerin sahip olduğu bilimin doğası anlayışların gelişme gösterdiği. $\quad \begin{array}{ll}2,8 \\ \quad\end{array}$

S23 Bilimin doğası etkinlikleri ile öğrencilerin kavramsal anlamalarında, $\quad 1 \quad 2,8$ bilimsel süreç becerilerinde gelişmeler olduğu.

S24 Farklı ülkelerdeki öğrencilerin bilim insanı hakkında benzer basmakalıp $\quad \begin{array}{ll}2,8 \\ \quad 2\end{array}$ algilara sahip olduğu.

S25 Bilimin doğası alanında araştırmacı olarak deneyimlerin, sahip olunan $\quad \begin{array}{ll}2,8 \\ \quad 2\end{array}$ değer ve inançların sınıf ortamına yansıdığını, öğrencilerle iletişimi etkilediği.

S26 Sınıf öğretmenlerinin bilimin doğasına ilişkin görüşleri ; cinsiyet, çalışma $\quad 1 \quad 2,8$ süresi, laboratuarı kullanma sıklığı, yüksek lisans eğitim durumu, bilimin doğası etkinliklerini kullanma sıklığı değişkenleri açısından anlamlı bir fark gözetmezken ; okutulan sınıf düzeyi, mezun olunmuş eğitim kurumları, okullarda laboratuar bulunması ve okulların eğitim-öğretim faaliyet süreleri açısından anlamlı bir fark olduğu.

Toplam

Tablo 7 incelendiğinde 2013 yılından itibaren bilimin doğası alanında yapılmış olan tezlerde ulaşılan sonuçların \%19,6’sının ‘Çalışmanın bilimin doğası görüşlerini olumlu yönde etkilediği.'olarak en sık ulaşılan sonuç olduğu ve \%11,2'sinin 'Öğretmen ve öğretmen adaylarının bilimin doğası ve içerik alan bilgisi açısından yetersiz kaldıkları.'sonucunun ise en sık rastlanan diğer sonuç olduğu görülmektedir. İncelenen çalışmalardan bir tanesi felsefe alanında yapılmıştır. Bundan dolayı sonuçlar kısmında çalışmanın bulgularına yer verilememiştir. 


\section{Bilimin Doğası Hakkında 2013 Yılından İtibaren Yayımlanmış Tezlerin}

\section{Araştırma Sonucu Önerilerine Göre İncelenmesi}

Tablo 8'te 2013 yılından itibaren bilimin doğası alanında yayımlanmış olan tezlerin yürütülmesinin ardından araştırmacıların yer verdiği öneriler genel maddeler halinde belirtilerek incelenen tezlerin önerilerinin dağılımlarına ve yüzdelik gösterimlerine yer verilmiştir.

Tablo 8. Bilimin Doğası Hakkında 2013 Yılından İtibaren Yayımlanmış Tezlerde Yer Alan Önerilerin Dă̆ılımı

\begin{tabular}{lllc}
\hline & Öneriler & f & \% \\
\hline Ö1 & $\begin{array}{l}\text { Öğretim programlarında bilim tarihi ve bilim felsefesi gibi derslerin yer } \\
\text { alması. }\end{array}$ & 15 & 15 \\
Ö2 & $\begin{array}{l}\text { Öğretmenlere hizmet içi eğitim programlarında bilimin doğasına yönelik } \\
\text { aktarımlara yer verilmesi. }\end{array}$ & 13 & 13 \\
Ö3 & Bilimin doğasını içeren etkinliklerin üniteler kapsamında yer alması. & 12 & 12 \\
Ö4 & $\begin{array}{l}\text { Bilimin doğası alanında daha detaylı özel durum çalışmalarının } \\
\text { yürütülmesi. }\end{array}$ & 8 & 8 \\
\hline Ö5 & $\begin{array}{l}\text { Bilimin doğasının öğretiminde farklı öğretim yöntem ve tekniklerinin } \\
\text { kullanılması. }\end{array}$ & 8 & 8 \\
\hline Ö6 & Bilim ve teknoloji kapsamında projeler hazırlanması. & 7 & 7 \\
Ö7 & Araştırmaların daha geniş bir örneklem incelenerek yapılması. & 7 \\
\hline Ö8 & Bilimin doğası ve sosyal konularla ilgili nitel araştırmaların yapılması. \\
Ö9 & $\begin{array}{l}\text { Ders kitaplarının içeriklerinin bilimsel okuryazarlık açısından } \\
\text { zenginleştirilmesi. }\end{array}$ & 5 & 5 \\
\hline Ö12 & Bilim teknoloji sosyal değişim derslerinin yeniden düzenlenmesi. & 3 \\
\hline Ö10 & Bilimsel bilginin günlük hayata aktarımının kolaylaştırılması. & 3 & 3 \\
\hline geliştirilmesinde öğrencilere eşit imkânlar sunulması. & Bilim ve teknoloji kapsamında projeler hazırlanması. & 3 \\
\hline
\end{tabular}


Ö15 Disiplinler arası çalışmaların yapılması.

Ö16 Bilim tarihi derslerinin yeniden düzenlenmesi.

$1 \quad 1$

Ö17 Bilimin doğası öğretiminde okul dışı çevre eğitimlerinin kullanılması. $\quad 1 \quad 1$

Ö18 Bilimin doğası alanında ölçek geliştirme çalışmaları yapılması.

$1 \quad 1$

Ö19 Bilimin doğası öğretiminde etkileşimli kısa tarihsel hikâyelerle bilim $1 \quad 1$ insanlarının hayatlarını içeren kitap hazırlanması.

Ö20 Bilimin doğasının öğretiminde öğretmenlerin karşılaştıkları zorlukların, $\quad 1 \quad 1$ deneyimlerin, çözüm önerilerinin vb. paylaşılabileceği resmi bir veri tabanı oluşturulması.

Tablo 8'de 2013 yılından itibaren bilimin doğası alanında yürütülmüş olan tezlerde araştırmalar sonucunda sunulan öneriler yirmi madde altında sınıflandırılmıştır. Tablo 9 incelendiğinde incelenen tezlerdeki önerilerin \%15'inin 'Öğretim programlarında bilim tarihi ve bilim felsefesi gibi derslerin yer alması.', \%13’ünün 'Öğretmenlere hizmet içi eğitim programlarında bilimin doğasına yönelik aktarımlara yer verilmesi.' ve \%12'sinin 'Bilimin doğasını içeren etkinliklere üniteler kapsamında yer alması.' şeklinde olduğu görülmektedir.

\section{Tartışma ve Sonuçlar}

Bu bölümde, 2013 yılından itibaren yayınlanmış olan tezlerden elde edilen araştırma bulgularına ve yorumlarına dayalı olarak ulaşılan sonuçlar ve bu sonuçlarla ilgili tartışmalar yer almaktadir.

Bu çalışmada 2013 yılı MEB yeni Fen bilimleri öğretim programının uygulanmaya geçmesi itibaren bilimin doğası ile ilgili yayımlanan yüksek lisans ve doktora tezleri, Türkiye'deki bilimin doğası ile ilgili yapılan çalışmalarda genel yönelimleri belirlemek amacıyla incelenmiştir. Araştırma sonucunda araştırma konusu kapsamında 49 ilgili tez 
ulaşılmış fakat 13 tezin kısıtlı olması ve yeterince veriye ulaşılamadığı için örneklem dışında bırakılmıştır. Sonuç olarak 36 tez örneklem grubuna dâhil edilerek ve analiz edilmiştir. Elde edilen tezler amaç, yöntem, örneklem, veri toplama araçları, araştırma yaklaşımı, sonuç ve öneriler değişkenleri bakımından analiz edilmiştir.

Yapılan araştırmada 2013 yılından itibaren bilimin doğası alanında yayınlanmış olan tezlerin yıllara ve araştırma türüne göre dağılımları incelendiğinde; 2013 yılında yayınlanan 12, 2014 yılında yayınlanan 14 ve 2015 yılında yayınlanan 10 tez olduğu görülmektedir. Yıllara göre yayınlanmış tezlerin sayılarının birbirine yakın olduğu ve belirgin bir farklılık olmadığ1 gözlenmiştir. Araştırma türü olarak incelendiğinde ise 2013, 2014 ve 2015 yıllarında bilimin doğası ile ilgili 7 şer tane olmak üzere toplam 21 yüksek lisans tezinin yapıldığı; 2013 yılında 5, 2014 yılında 7 ve 2015 yılında 3 olmak üzere toplam 15 doktora tezinin çalışıldığ görülmektedir. Yüksek lisans çalışmaları ağırlıklı olduğu görülmektedir. Yüksek lisans bir alanda uzmanlaşmak iken, doktora ise daha çok evrensel bilgi birikimine katkıda bulunmayı gerektirir. Ülkemizde yapılan çalışmaların evrensel bilgiye katkı yapacak uluslararası literatürü etkileyecek düzeyde yoğunlaşmadığı görülmektedir.

2013 yılından itibaren bilimin doğası konusunda yayınlanmış tezler amaç değişkeni açısından ele alındığında amaçlar 17 başlık altında sınıflandırılmıştır. Yapılan incelemeler sonucunda 'Bilimin doğasına yönelik bakış açılarını araştırmak' en sı1k rastlanan amaç olarak öne çıkmaktadır. Benzer şekilde araştırmada 'Bilimin doğasına yönelik bakış açıları belirlemek ve bilimin doğasının ögretimi ' ve 'Bilimin doğasına yönelik görüşler, eleştirel düşünme becerileri ve akademik başarıyı incelemek 'gibi amaçların frekanslarının yüksek değerler alması birçok araştırmanın bilimin doğasına yönelik görüşleri belirlemeyi hedeflediğini bulgular bölümündeki Tablo 2 den kolaylıkla görülmektedir. Bunlara ek olarak , 'Sosyobilimsel konularda akll yürütme ile bilimsel bilginin doğasını anlama arasındaki ilişkiyi belirlemek', 'Öz inceleme yoluyla uygulamaların nasıl gerçekleştiğini keşfetmek' ve 
'Bilimin nasıl ilerlediğine yanıt aramak', 'bilimin doğası ve bilim felsefesi ilişskilerini incelemek', 'bilimin doğasının zihinsel algılama sürecini değerlendirmek' gibi amaçların daha az incelendiği görülmüştür. Örneklemi oluşturan çalışmaların genelinin bilimin doğasına yönelik görüşler üzerine mevcut durumu belirlemeye yönelik yapıldığını göstermektedir.

Üçüncü değişken olarak ele alınan araştırma yaklaşımı açısından tezler incelendiğinde

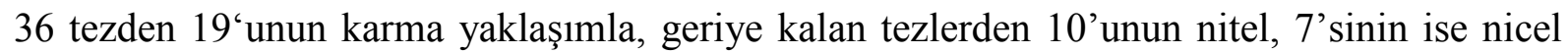
yaklaşımla yürütüldüğü görülmüştür. Araştırma bulgularının yıllara göre dağılımları incelendiğinde karma yaklaşımın her yıl en fazla kullanılan yaklaşım olduğu belirlenmiştir. Yapılan çalışmadan farklı olarak Erdaş, Doğan ve İrez (2016), yürüttükleri araştırmada bilimin doğası alanında yapılmış çalışmalarda kullanılan yöntem dă̆ı̆ımı incelenildiğinde araştırmacıların en fazla nicel yöntemleri tercih ettiği bulgularına ulaşılmıştır. Benzer şekilde bilimin doğası alanında çalışmasını yürüten İnce ve Özgelen (2015) ise yaptıkları incelemeler sonucunda nitel yaklaşımla yürütülen çalışmaların daha fazla olduğu sonucunu elde etmiştir. Yürütülen çalışmalarda araştırmaya dâhil edilen çalışma örneklemlerinin türlerinin farklı olması, incelenen çalışmaların belirli yıllarla sınırlandırılması farkı sonuçlara ulaşılmasında etkili olmuş olabilmektedir.

Karma yaklaşım, nitel ve nicel yaklaşımların tek bir çalışmada birleştirilmesiyle oluştuğu, yürütülen araştırmalara hem süreç hem de sonuç açısından katkı sağladığı dikkate alındığında; araştırmaların zenginliği ve güvenirliği açısından daha etkili öneriler ortaya koyduğu söylenilebilir (Tashakkori ve Teddlie, 1998, 2003; Creswell, 2003; Leech ve Onwuegbuzie, 2009 ; Gökçek, Babacan, Kangal, Çakır ve Kül, 2013). Gerçek görüşleri ortaya çıkarmak için ihtiyaç duyulan nitel araştırmalar ve çalışılan alanın genel özelliklerini ortaya çıkaran nicel araşıtımaları birleştiren karma yaklaşımın eğitim araştırmalarında daha fazla kullanıldığı görülmektedir(Şimşek ve Yıldırım, 2011; Çil ve Çepni, 2012; Creswell, 2013). Karma yaklaşım araştırmacılar tarafından daha sık başvurulmasıyla birlikte 2000'li yıllardan 
sonra yükselişe geçmiştir (Şimşek ve Yıldırım, 2011; Creswell, 2013). Ülkemizde yapılan bu çalışmalar, yöntem seçiminde ve veri elde etme süreçlerinde durumun gereği olanın yerinde ve doğru bir şekilde tercih edildiğini göstermektedir. Bilimin doğası konusunda da hem nitel hem de nicel araştırma desenlerini bir arada yoğunlukla kullanabiliyor olmamız bize süreci ve özel durumları da yeterince etkili bir şekilde ölçebildiğimizi göstermektedir.

Araştırmada bilimin doğası alanında ele alınan tezler, araştırma modellerine göre incelendiğinde yarı deneysel modelin en fazla tercih edildiği görülmektedir. Bununla birlikte deneysel model, durum çalışması, karma model, tarama modeli, olgu bilim gibi modeller de sırasıyla sıkça başvurulan yöntemler arasında yer almaktadır. Erdaş,Doğan ve İrez (2016) çalışmasında örnek olay incelemesi ve tarama yönteminin araştırmalarda en çok tercih edilen yöntemler olduğunu ifade etmiştir. Çalışmada kullanılan veri analiz yöntemlerinin dağılımına bakıldığında en çok tercih edilen yöntemin betimsel analiz yöntemi olduğu görülmektedir. Benzer olarak İnce ve Özgelen (2015), tarafindan yürütülen araştırmada durum çalışmasının bilimin doğası alanında yapılmış olan araştırmalarda en çok tercih edilen model olduğu ve derleme ile doküman incelemesi deseninin daha fazla kullanıldığı sonucuna ulaşılmıştır. Bilimin doğası alanında yapılan çalışmalarda mevcut durumun analizi ve değerlendirilmesi ön planda tutulduğu anlaşılmaktadır. Bu durum araştırmacıların bilimin doğası ile ilgili olarak yeni ufuklar açmasından önce mevcut durumu algılama istekleri ile ilişkili olabileceği gibi bilimin doğası alanının soyut ve geniş birtakım boyutları barındırması nedeniyle özgünleştirilmesinin zor olabileceği düşünülmektedir. Son dönemlerde yapılan çalışmaların alanının kısıtlı kaldığı ve bu durumun yapılan çalışmaları kısır bir döngüye çevireceği araştırmacılar tarafından ifade edilmekle birlikte ilerleyen araştırmalarda bilimin doğasına farklı yöntemlerle bakılması gerektiğinden bahsedilmiştir (Deng, Chen, Tsai ve Chai, 2011; İnce ve Özgelen, 2015). 
Bilimin doğası alanında 2013 yılından itibaren yayınlanmış olan tezlerin örneklem seçimine göre dağılımları incelendiğinde 36 tezden 15'inde öğretmen adaylarının,14 tezde öğrencilerin, 3 tezde ise öğretmenlerin örneklem olarak alındıkları görülmektedir. Öğretmen adaylarının büyük bir kısmının fen bilgisi öğretmen adayı olduğu ve sınıf, sosyal bilgiler, biyoloji, kimya öğretmen adaylarının örneklem olarak daha az tercih edildiği dikkat çekmektedir. Öğrencilerin örneklem olarak incelendiği tezlerde ise ortaokul kısmındaki öğrencilerin daha çok tercih edildiği; lise ve okul öncesi öğrencileri üzerinde ise daha az çalışmanın olduğu belirlenmiştir. İnce ve Özgelen (2015) çalışmasında örneklem seçiminde öğrenci, öğretmen ve öğretmen adayı arasında birbirine yakın bir dağılım bulunmuştur. Benzer şekilde öğretmen adaylarından fen bilgisi öğretmenliği; öğretmenlerden fen ve teknoloji öğretmenleri; öğrencilerden ise ilköğretim düzeyindeki öğrenciler üzerinde yapılan incelemelerin sayısının fazla olduğu belirtilmiştir. Benzer şekilde Erdaş, Doğan ve İrez (2016) tarafindan yürütülen çalışmasında da öğretmen adayları ve ilkokul öğrencileri üzerinde yapılan çalışmaların sayısının daha fazla olduğunu belirtilmiştir.

Bilimin doğasının fen bilimleri ile ilişkilendirilmesi sonucunda çalışmaların fen bilgisi öğretmen adayları üzerinde yoğunlaştığı Tablo 5'te görülmektedir. Bu durum araştırmacıların çalışmalarını yürütürken bilimin doğasını fen bilimleri ile sınırlı olarak algıladıklarını gösteren bir veri olabilir. Oysaki bilim kavramı sadece fen ile sınırlı olmayıp çok geniş bir çerçeveye sahiptir. Bilimin doğası, bilim epistemolojisi ve bilme yolu olarak bilimle, bilimsel bilginin gelişiminde var olan inançlar ve değerlerle ilişkilidir (Lederman, 1992; Ayvac1, 2007). Bilimin doğasını fen bilimleri ile ilişkilendirmenin doğru olmadığı, bilimin doğasının tüm disiplinlerle ilişkili olduğu gerçeği incelenen tezlerde göz ardı edildiği görülmektedir. Benzer şekilde ele alınan örneklemlerin ortaokul düzeyinde olması da fen bilimleri derslerinin bilimin doğası ile ilişkilendirilmesini göstermektedir. Örneklem seçiminde öğrenci ve öğretmen adayı arasında birbirine yakın bir dağılım bulunmaktadır. Ayrıca öğretmenler ve 
bilim insanları ile yapılan çalışmaların sayısı ise oldukça azdır. Akademisyenlerle çalışmaların yapılmamış olması alanın eksikliğini göstermektedir. Bunlara ek olarak okul öncesi kısımda da araştırmaların azlığı dikkat çekmekle beraber Quigley, Pongsanon ve Akerson (2011) tarafından yapılan çalışma ile bilimin doğası eğitiminin küçük yaşlarda verilebilmesi gereği üzerinde vurgu yapıldığı görülmektedir.

Araştırma kapsamında ele alınan tezlerin nicel veri toplama araçları incelendiğinde ‘ Bilimin doğası ölçeği' nin en sık kullanılan nicel veri toplama aracı olduğu görülmektedir. Bununla birlikte 'Başarl testi' , 'Kavram testi' ve 'Bilimsel süreç becerileri ölçeğì' de nicel verileri toplamak için en çok tercih edilen araçlar arasında yer almıştır. Tezlerde nitel veri toplamak için ise en çok başvurulan araç 'Görüşme' olmakla birlikte 'Gözlem', 'Video kaydı', 'Ders planı','Araştırmacı notları','Çalışma yaprakları', ' İ̧̧erik sunum formu' , 'Öğrenci çalışmaları' ve 'Öğretmen dokümanları' da nitel verilerin toplanmasında kullanılmıştır. Veri toplama araçları incelendiğinde yapılan araştırmaların birçoğunun karma yaklaşıma dayalı sürdürülmesi nedeniyle nitel ve nicel veri toplama araçları bir arada kullanılmıştır. Ayrıca kullanılan ölçeklerin çoğunluğu yabancı kaynaklardan çevrilerek Türkçeye uyarlanmıştır. Kullanılan veri toplama araçlarının araştırmanın diğer değişkenlerine paralellik gösterecek şekilde mevcut durumu belirlemeye yönelik oldukları ve özgünlük taşımadıkları görülmektedir. Çalışmaya benzer nitelikte İnce ve Özgelen (2015) tarafından yürütülen çalışmada araştırmaların verilerinin büyük çoğunluğunun görüşme tekniği ve gözlem ile toplandığı belirtilmiştir.

Araştırma kapsamında ele alınan sonuçlar değişkenine göre tezler incelendiğinde 26 madde olarak belirlenmiştir. İnceleme sonunda en çok ulaşılan sonuçların 'Çalışmanın bilimin doğası görüşlerini olumlu yönde etkilediği.' ve ' Öğretmen ve öğretmen adaylarının bilimin doğası ve içerik alan bilgisi açısından yetersiz kaldıkları.' maddeleri olduğu görülmektedir. Sonuçlar incelendiğinde yürütülen çalışmaların var olan bir yöntemin bilimin 
doğası görüşleri üzerine etkisinin ve örneklem olarak alınan kesimin bilimin doğasına yönelik sahip olduğu mevcut durumun ele alındığı görülmektedir. Kısacası yürütülen çalışmalar genellikle durum belirleme olarak ele alınmakla birlikte yeni ve farklı yönelimlere rastlanmamıştır. Benzer şekilde Erdaş, Doğan ve İrez (2016) tarafından Türkiye'de bilimin doğası hakkında yapılan çalışmaların sonuçlarını analiz eden araştırmada öğrenci, öğretmen ve öğretmen adaylarının kavramlarının geliştirilmesine yönelik uygulamalarda olumlu sonuçlar elde edildiği gözlemlenmiştir.

İlgili tezler araştırmacıların sunmuş olduğu öneriler kapsamında incelenmiş ve öneriler 20 madde altında sınıflandırılarak frekans dağılımları Tablo 7'de gösterilmiştir. Bu kapsamda en fazla 'Ö̆gretim programlarında bilim tarihi ve bilim felsefesi gibi derslerin yer almasl.' önerisine rastlanmakla birlikte 'Öğretmenlere hizmet içi eğitim programlarında bilimin doğasına yönelik aktarımlara yer verilmesi.', 'Daha detayl özel durum çalışmalarının yürütülmesi.' ve 'Farklı ögrretim yöntem ve tekniklerinin kullanılması.' önerilerine de sıkça yer verildiği görülmüştür. Bunun yanında önerilerin sınıflandırılması ile bilimin doğası alanında eksiklikler ve yapılması önem arz eden kısımlar belirlenmiştir. Bu durum da yeni araştırmalar için sınıflandırılmış öneriler frekanslarının literatürdeki eksiklikleri gidermeye yardımcı olacağı düşünülerek yapılacak olan çalışmaların yürütülmesi sürecinde dikkate alınması önerilmektedir.

Genel olarak yapılan araştırma 2013 yılı Fen Bilimleri Öğretim Programı’ndan itibaren bilimin doğası alanının çalışma alanını incelemesi nedeniyle tezlerin yayınlanma tarihi açısından 3 yılı kapsamasından dolayı sınırlı kalmakla birlikte değişkenleri incelemek yönünden geniş tutulmuştur. Bilimin doğası üzerinde benzer bir çalışma yürüten İnce ve Özgelen (2015) çalışmasında bilimin doğası alanında 2010-2014 yılları arasında yayınlanmış olan makaleleri içerik analizi ile çeşitli değişkenler açısından incelemiştir. Yapılan çalışmada makaleler üzerine yayın yılı, yaklaşım, desen, örneklem ve veri toplama araçları değişkenleri 
çerçevesinde araştırma yapılmıştır. Araştırma bulgularında bilimin doğası konusunun popülerlik kazandığından ve makale sayılarında artış olduğundan söz etmekle beraber nitel araştırmaların daha yoğunlukta olduğu, durum çalışmasının ve doküman analizinin fazlaca uygulandığına ulaşılmıştır. Bunlara ek olarak genellikle öğrencilerle daha sonra da öğretmen adaylarıyla çalışmalar yürütüldüğü bulgularda yer almaktadır. Yürütülen bu çalışmada ise bilimin doğası alanında yapılmış olan tezlerde karma yaklaşımın daha fazla kullanıldığı, genellikle yürütülen çalışmaların yarı deneysel ve deneysel yöntemlerle ele alındığı, doküman analizi gibi çalışmalara yeterince yer verilmemiş olduğu ve bunların yanında örneklem olarak genellikle öğretmen adaylarının daha sonra da öğrencilerin tercih edildiği gibi daha farklı bulgulara rastlanmaktadır. İnce ve Özgelen (2015) benzer şekilde yürüttükleri çalışmada bilimin doğası alanında yapılan çalışmalarda örneklem seçiminde öğrenci, öğretmen ve öğretmen adayları arasında birbirine yakın bir dağılım bulunduğunu belirtmiştir. Ayrıca yapılan araştırma sonucunda incelenen makalelerde ve tezlerde genellikle fen bilgisi öğretmen adaylarının ve fen bilgisi öğretmenlerinin üzerinde çalışılması, nitel verilerin toplanmasında görüşme ve gözlemin kullanılma frekansının yüksek olması gibi bulgular yürütülen araştırma ile benzerlik göstermektedir. Bu duruma benzer olarak İnce ve Özgelen (2015), çalışmasında Öğretmen adaylarından fen bilgisi öğretmenliği öğrencileri ile yapılan araştırmalarının fazla olduğunu belirtmiştir. Ayrıca yapılan araştırma sonucunda incelenen makalelerde ve tezlerde genellikle fen bilgisi öğretmen adaylarının ve fen bilgisi öğretmenlerinin üzerinde çalışılması, nitel verilerin toplanmasında görüşme ve gözlemin kullanılma frekansının yüksek olması gibi bulgular yürütülen araştırma ile benzerlik göstermektedir.(İnce ve Özgelen, 2015).

Genel olarak bakıldığında yapılan çalışma belirli yıl aralığında sınırlı olmasına karşın araştırmanın sonuçları ileride yürütülecek çalışmalara yol gösterebilir. Alan yazında bulunan eksiklikleri ve üzerinde çalışılmamış olan alanları göstermesi bakımından araştırmacılar için orijinal çalışmalara yön gösterebilir. 


\section{Öneriler}

Bu kısımda yürütülen araştırmanın sonucunda geliştirilen önerilere yer verilmiştir.

Çalışmada incelenen değişkenler arttırılarak daha geniş bir zaman aralığında yapılmış olan araştırmalar seçilip kapsamlı bir araştırma yürütülebilir.

Araştırma türü olarak yüksek lisans tezlerinin doktora tezlerine oranla daha fazla yer aldığı belirlenmiştir. Bilimin doğası alanı ile ilgilenen araştırmacıların ileride yapılacak olan çalışmalarda doktora seviyesinde yer alacak çalışmalara ağırlık verilebilir.

İlerleyen yıllarda yapılacak çalışmaların doküman analizi, eylem araştırması, fenomenolojik çalışmalar, kültürel çalışmalar, özel durum ve öz-inceleme gibi farklı yöntemlerle yürütülmesi ile bilimin doğası alanında yapılacak araştırmaların çerçevesini geliştirilebilir.

Mevcut durumu analiz etme ya da var olan bir yöntemi uygulama gibi durum çalışmaları yerine özgün bir materyal tasarlayıp bu materyalin bilimin doğası alanında etkililiği, bilimin doğası ile farklı alanların etkileşimi, bilimin doğası öğretiminde araştırmacının özgün yöntemleri kullanılması gibi orijinal çalışmalar yürütülerek dünya literatürüne katkıda bulunulabilir.

'Sosyobilimsel konularda akıl yürütme ile bilimsel bilginin doğasını anlama arasındaki ilişkiyi belirlemek', 'Öz inceleme yoluyla uygulamaların nasıl gerçekleştiğini keşfetmek' ve 'Bilimin nasıl ilerlediğine yanıt aramak' gibi frekans dağılımının az olduğu ya da araştırma sürecinde rastlanmayan orijinal amaçlar üzerine araştırmalar yürütülebilir.

Yapılan incelemelerin sonuçları dikkate alındığında bilim insanı ve öğretmen, öğretmen gibi az çalışılmış olan örneklemler üzerinde yapılacak araştırma sayısının 
arttırılması; öğretmen adayları örneklemlerinde; fizik öğretmen adayları gibi çalışılmamış örneklemlerin veya az çalışılmış öğretmen adayları örneklemleri üzerinde çalışılması araştırmacılara önerilebilir.

Ele alınacak herhangi bir örneklem üzerinde boylamsal araştırmalar sürdürülebilir.

Farklı branş öğretmen adayları üzerinde daha geniş bir örneklem oluşturularak araştırmalar yapılabilir.

Bilimin doğası alanını fen bilimlerinden farklı olarak diğer alanlarla olan ilişkilerini inceleyecek çalışmalar yürütülebilir.

Yapılan araştırmanın sonucunda yabancı kaynaklardan uyarlanan ölçeklerin gerçeği yansıtma durumlarının yanıltıcı olabileceği göz önüne alınarak yeni çalışmalarda veri toplama araçlarının araştırmanın amacına, ele alınacak örneklemin özelliklerine göre düzenlenmesi ve kullanılacak araçların bu durumlara dikkat edilerek seçilmesi ya da geliştirilmesi önerilmektedir.

Benzer konularda yapılacak araştırmalarda tarama yapılacak zaman diliminin daha geniş alınması; ayrıca benzer şekilde yürütülecek çalışmalarda sonuçlar değişkeninin daha farklı sınıflamalarla gruplandırılması önerilebilir.

$\mathrm{Bu}$ araştırmada sadece tezler incelenmiştir. Yapılacak olan yeni çalışmalarda makaleler de örnekleme dâhil edilebilir.

Benzer şekilde makaleler ile tezler incelenip karşılaştırmalar da yapılabilir.

Araştırma sonuçlarında elde edilen verileri sonuca yönelik olduğu için sürece yönelik çalışmalar yürütülerek çıkan sonuçların sebepleri irdelenebilir.

Aynı araştırma farklı araştırmacılar tarafindan yapılarak sonuçları karşılaştırılabilir.

Öğretim programına bilimin doğasının etkisi üzerine farklı yöntemlerle araştırmalar yürütülebilir. 
Karma yaklaşımın kullanılması ile araştırmalarda eksik kalan ya da fark edilmeyen noktalar tamamlanabilir.

\section{Makalenin Bilimdeki Konumu (Yeri)}

Matematik ve Fen Bilimleri Eğitimi Bölümü/ Fen Bilgisi Eğitimi Anabilim Dalı

\section{Makalenin Bilimdeki Özgünlüğü}

Literatürde mevcut çalışmalar incelendiğinde; son y1llarda bilimin doğası tüm dünyada olduğu gibi ülkemizde de fen eğitiminde ilgilenilen bir alan haline gelmiştir. Bilimin doğası konusunda öğrencilerin, öğretmenlerin görüşleri gibi alanlarda yapılan çalışmalara göre içerik analizi çalışmalarının az olması ve bu araştırmanın bilimin doğası üzerine yapılan çalışmaların genel çerçevesini çizmesi ve bu alandaki çalışmaların yetersiz olduğu alanların belirlenip ileriki araştırmacılara yol göstermesi açısından böyle bir araştırmanın gerekliliğini ortaya koymaktadir. 
Ek 1. Bilimin Doğası Hakkında 2013 Yılından İtibaren Yayımlanmış Tezlerden Araştırma Örnekleminde Yer Alan Tezler

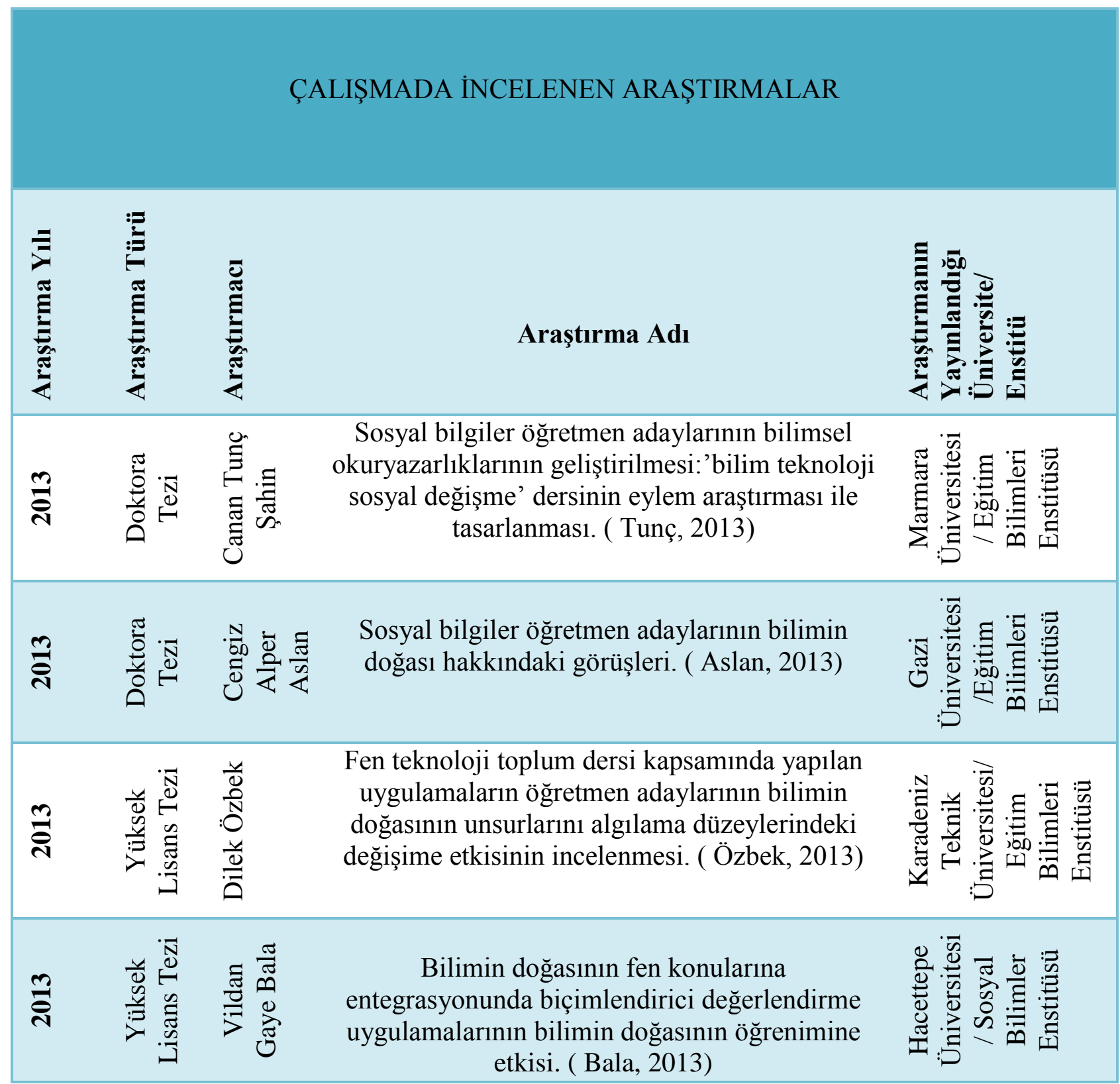




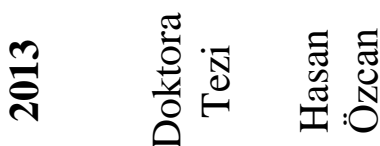 \\ Fen bilgisi öğretmen adaylarının fen içeriği ile ilişkilendirilmiş bilimin doğası konusundaki pedagojik alan bilgilerinin gelişimi. (Özcan, 2013)}

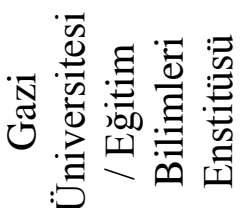

\begin{tabular}{|c|c|c|}
\hline 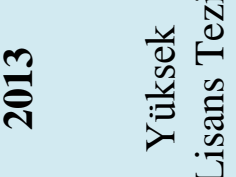 & 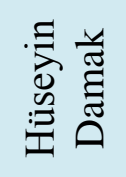 & $\begin{array}{l}\text { Bilimin özerkliği ve bilim- devlet ilişkileri. } \\
\text { (Damak, 2013) }\end{array}$ \\
\hline
\end{tabular}

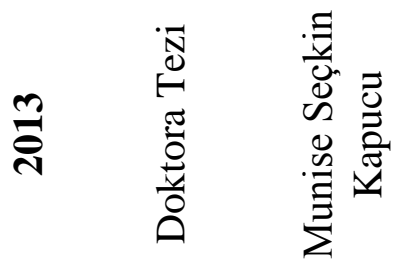

Fen ve teknoloji dersinde belgesel kullanılmasının 8. sınıf öğrencilerinin hücre ile kuvvet konularındaki başarılarına ve bilimin doğası hakkındaki görüşlerine etkisi. (Seçkin,

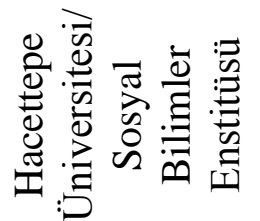
2013)

\begin{tabular}{|c|c|c|c|}
\hline 吾 & 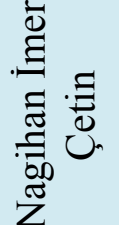 & $\begin{array}{l}\text { Fen bilgisi öğretmen adaylarının bilimin doğası } \\
\text { anlayışlarının geliştirilmesinde hipermedyanın } \\
\text { kullanılması: özdüzenleme faktörünün } \\
\text { incelenmesi. (İmer 2013) }\end{array}$ & 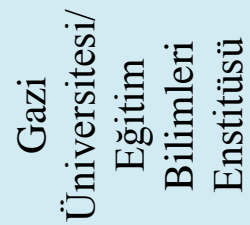 \\
\hline
\end{tabular}

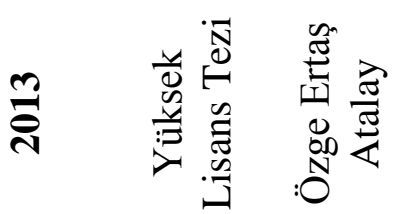

Bilim insanlarının ve ilköğretim 2. kademe fen ve teknoloji öğretmenlerinin bilimin doğasına ilişskin görüşlerinin incelenmesi. ( Ertaş, 2013)

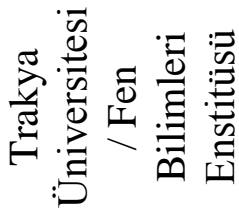

Biyoloji öğretim programı ile biyoloji öğretmen adaylarının bilim ve bilimin doğasına yönelik

bakış açılarının değerlendirilmesi. ( Yener, 2013)

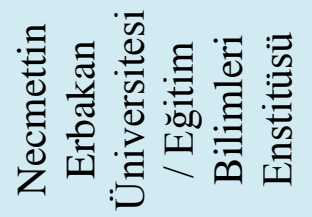

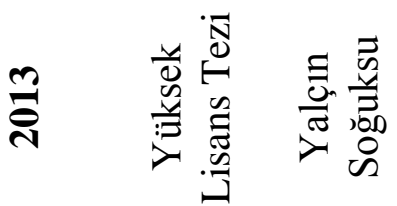

Biyoloji öğretmen adaylarının biyolojik okuryazarlığının değerlendirilmesi. ( Soğuksu, 2013)
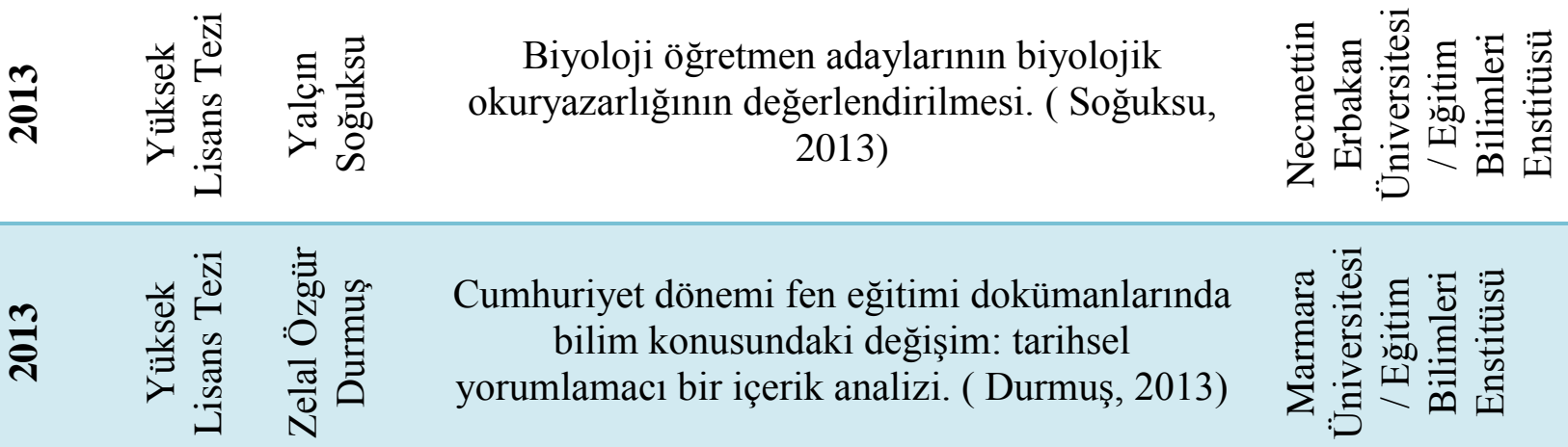

Cumhuriyet dönemi fen eğitimi dokümanlarında bilim konusundaki değişim: tarihsel yorumlamacı bir içerik analizi. ( Durmuş, 2013)

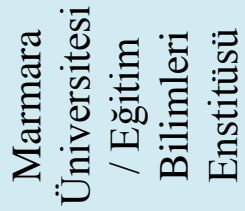

Müfredat dışı biyoteknoloji etkinliklerinin öğrencilerin biyoteknoloji bilgilerine ve bilimin doğası hakkındaki görüşlerine etkisi. ( Sönmez, 2014)

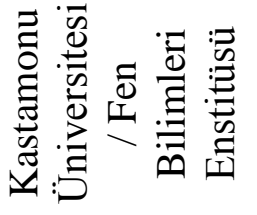




Doğrudan-yansitici yaklaşım açisından
desenlenen iki tamamlayıc1 dersin bilimin
doğasına ilişkin anlayışlara etkisi. (Gün, 2014)

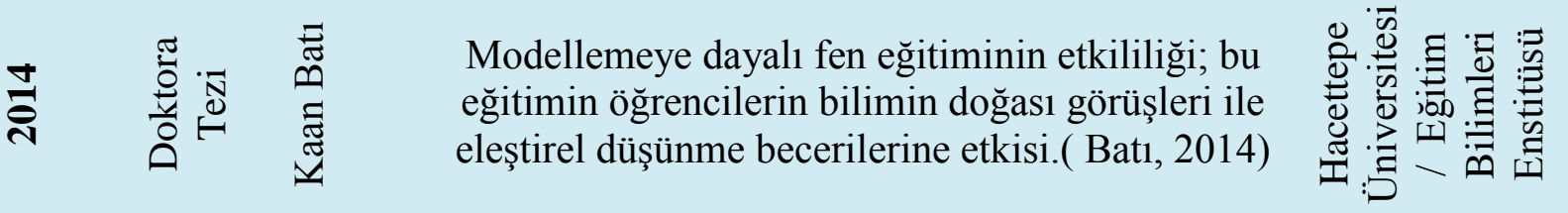

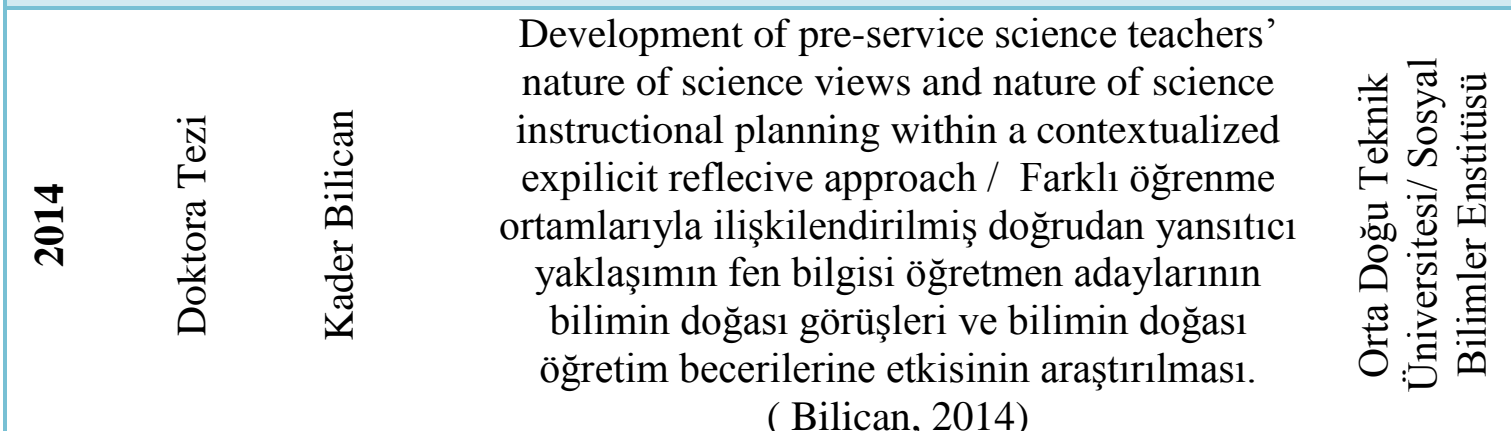

A study on science teachers' pedagogical content
knowledge and content knowledge regarding cell
division / Fen bilgisi ögretmenlerinin hücre
bölünmesi konusundaki pedagojik alan bilgisi
üzerine bir çalışma. (Şen, 2014)




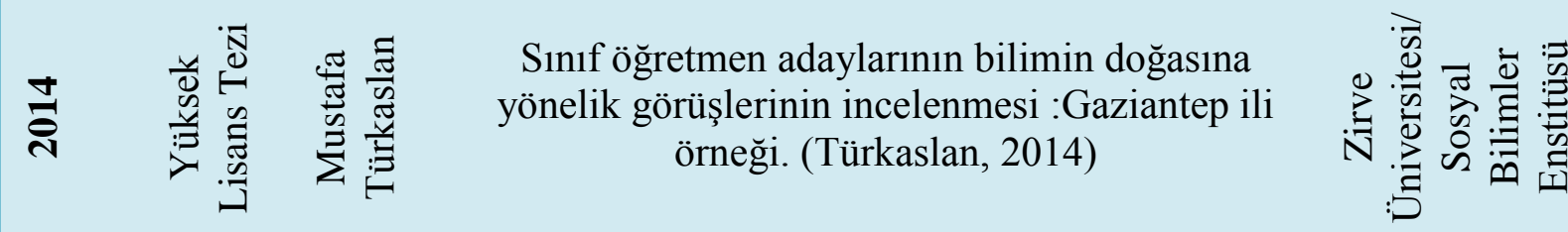

\begin{tabular}{|c|c|c|c|}
\hline 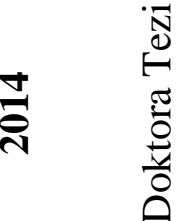 & $\begin{array}{l}\frac{\bar{d}}{3} \\
\frac{\pi}{1000} \\
\frac{\pi}{2} \\
0\end{array}$ & $\begin{array}{l}\text { Doğrudan yansıtıcı yaklaşıma dayalı öğretimin } \\
\text { kimya öğretmen adaylarının bilimin doğası } \\
\text { görüşlerine etkisi. (Ağlarcı, 2014) }\end{array}$ & 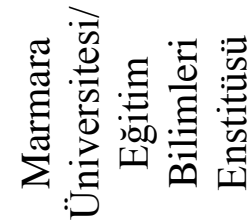 \\
\hline
\end{tabular}

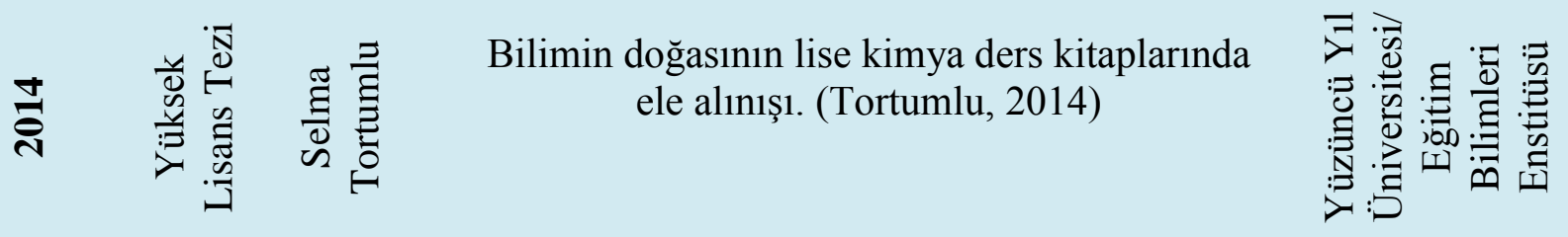

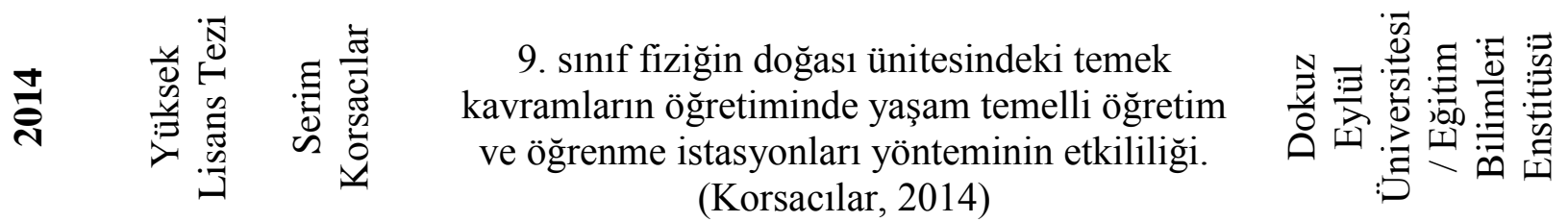

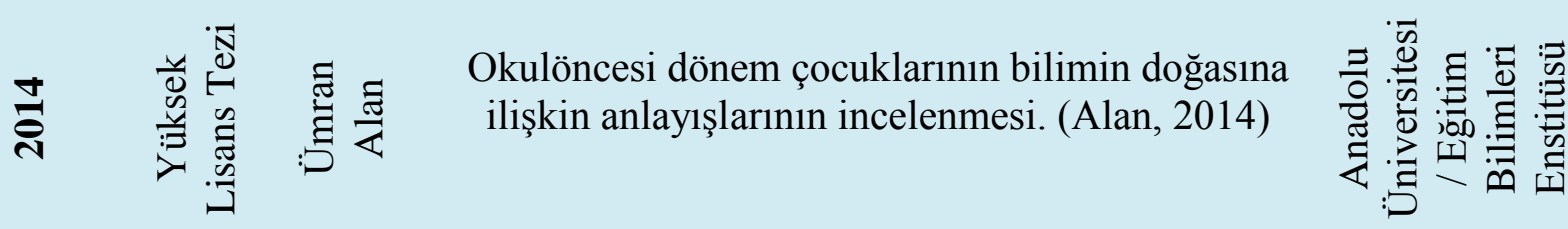

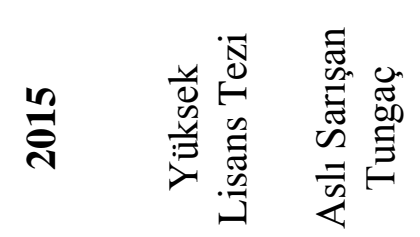

Fen bilgisi öğretmenlerinin okul dışı ( doğa deneyimine bağl1) çevre eğitimine yönelik özyeterlilik algıları, çevre bilgileri ve çevresel tutumlarının incelenmesi: Mersin ili örneği. (Tungaç, 2015)

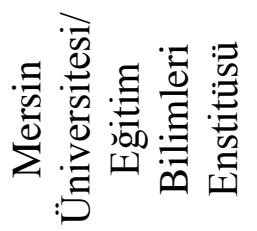

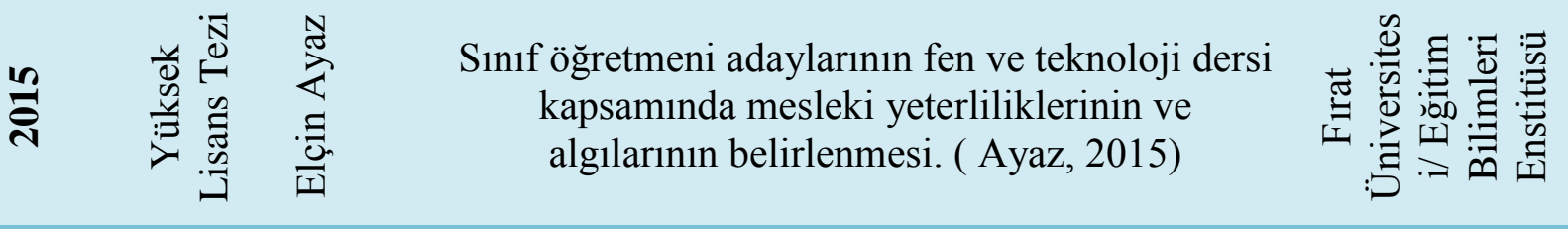

\begin{tabular}{|c|c|c|}
\hline 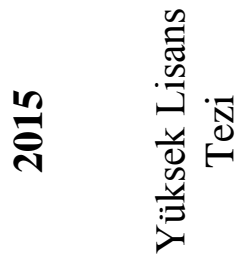 & 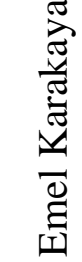 & $\begin{array}{l}\text { Bilimsel bilginin doğasını anlama ve sosyo- } \\
\text { bilimsel konularda akıl yürütme. (Karakaya, } \\
\text { 2015) }\end{array}$ \\
\hline
\end{tabular}

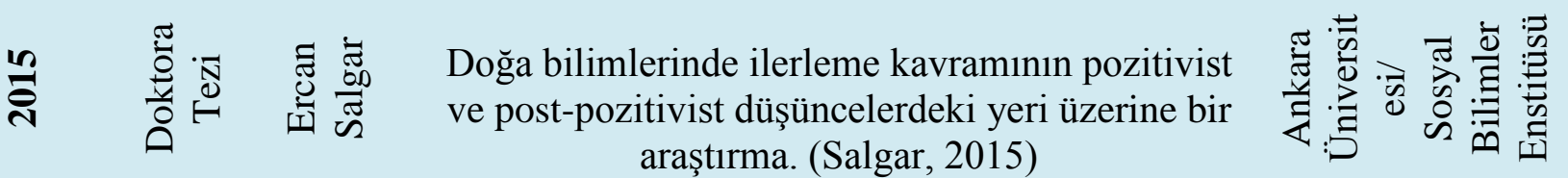




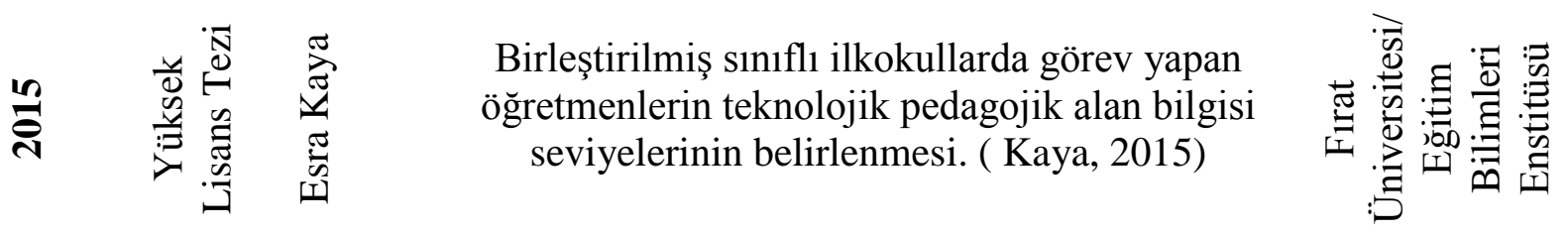

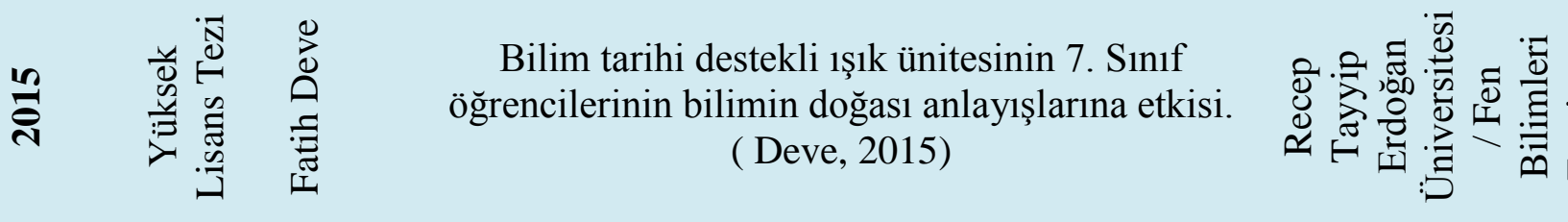

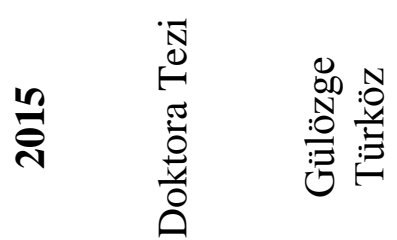

Bilimin doğası etkinliklerinin öğrencilerin kavramsal anlama, bilimsel süreç becerileri ve bilimin doğası anlayışlarına etkisi. (Türköz, 2015)

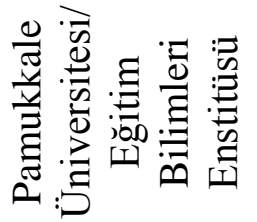

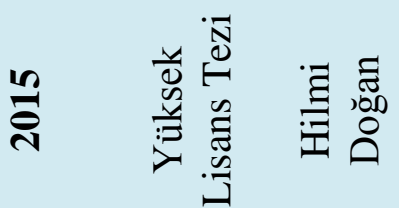

Farklı ülkelerden 11 -13 yaş aralığındaki öğrencilerin bilim ve bilim insanı hakkındaki görüşleri. (Doğan, 2015)
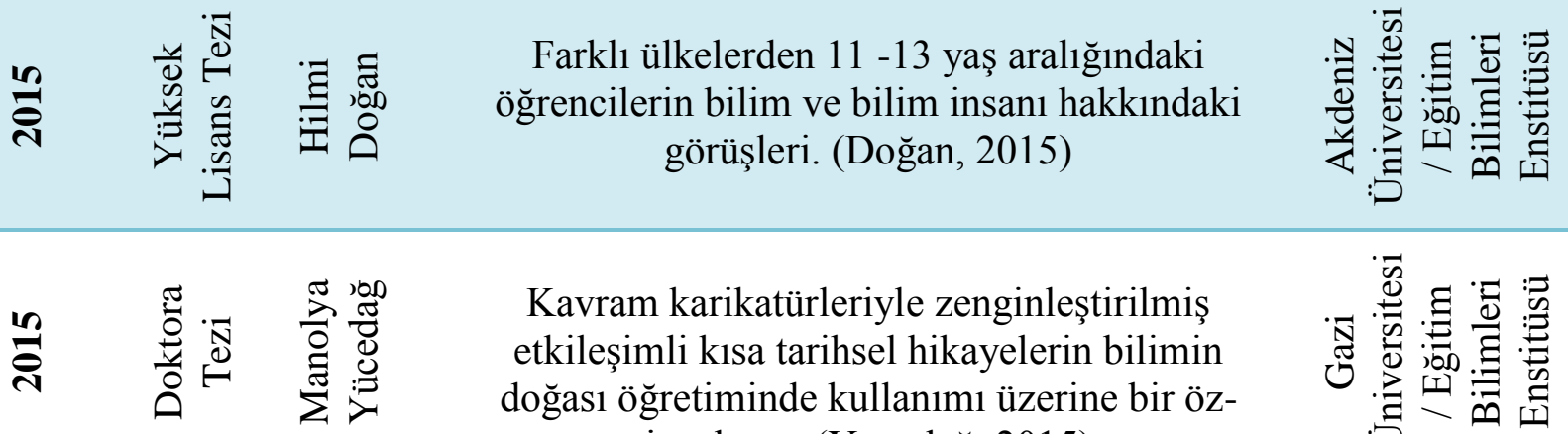

Kavram karikatürleriyle zenginleştirilmiş etkileşimli kısa tarihsel hikayelerin bilimin doğası öğretiminde kullanımı üzerine bir özinceleme. (Yücedağ, 2015)

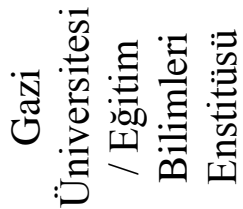

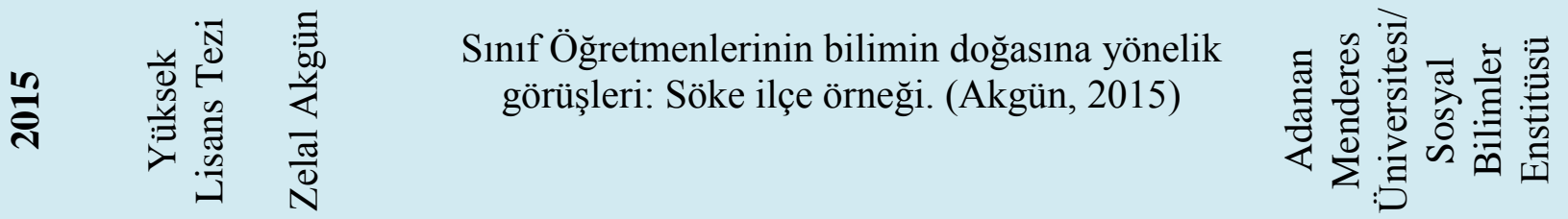




\section{Kaynakça}

Ağlarcı, O. (2014). Doğrudan-yansıtıcı yaklaşıma dayalı öğretimin kimya öğretmen adaylarının bilimin doğası görüşlerine etkisi. Doktora tezi, Marmara Üniversitesi, İstanbul.

Akgün, Z.(2015). Sınıf öğretmenlerinin bilimin doğasına yönelik görüşleri: Söke ilçe örneği. Yüksek Lisans tezi, Adnan Menderes Üniversitesi, Aydın.

Alan, Ü.(2014).Okulöncesi dönem çocuklarının bilimin doğasına ilişkin anlayışlarının incelenmesi. Yüksek Lisans tezi, Anadolu Üniversitesi, Eskişehir.

American Assocation for the Advancement of Science (AAAS). (1990). Project 2061:

Science for all Amerians. New york, Oxsford: Oxford Universty Press.

Aslan, C., A. (2013).Sosyal bilgiler öğretmen adaylarının bilimin doğası hakkındaki görüşleri. Doktora tezi, Gazi Üniversitesi, Ankara.

Ayas, A. (1995) Fen bilimlerinde program geliştirme ve uygulama teknikleri üzerine bir çalışma:iki çağdaş yaklaşımın değerlendirilmesi.Hacettepe Üniversitesi Eğitim Fakültesi Dergisi, 11 : 149-155.

Ayaz, E. (2015). Sınıf öğretmeni adaylarının fen ve teknoloji dersi kapsamında mesleki yeterliklerinin ve algılarının belirlenmesi. Yüksek Lisans tezi, Fırat Üniversitesi, Elazı $\breve{g}$.

Ayvacı, H. Ş. (2007). Bilimin doğasının sınıf öğretmeni adaylarına kütle çekim konusu içerisinde farklı yaklaşımlarla öğretilmesine yönelik bir çalışma. Yayımlanmamış doktora tezi, Karadeniz Teknik Üniversitesi, Trabzon.

Bala, G. (2013). Bilimin doğasının fen konularına entegrasyonunda biçimlendirici değerlendirme uygulamalarının bilimin doğasının öğrenimine etkisi. Yüksek Lisans tezi, Hacettepe Üniversitesi, Ankara. 
Bakırcı, H. (2014). Ortak bilgi yapılandırma modeline dayalı öğretim materyali tasarlama, uygulama ve modelin etkililiğini değerlendirme çalışması: Işık ve ses ünitesi örneği. Doktora tezi, Karadeniz Teknik Üniversitesi, Trabzon.

Batı, K.(2014).Modellemeye dayalı fen eğitiminin etkililiği; Bu eğitimin öğrencilerin bilimin doğası görüşleri ile eleştirel düşünme becerilerine etkisi. Doktora tezi, Hacettepe Üniversitesi, Ankara.

Benli, E.(2014).Fen öğretiminde ortak bilgi yapılandırma modelinin ilköğretim öğrencilerinin bilişsel ve duyuşsal öğrenmeleri üzerine etkilerinin incelenmesi. Doktora tezi, Gazi Üniversitesi, Ankara.

Bilican, K. (2014).Development of pre-service science teachers' nature of science views and nature of science instructional planning within a contextualized expilicit reflective approach. Doktora tezi,Orta Doğu Teknik Üniversitesi,Ankara.

Boran,G., H. (2014). Argümantasyon temelli fen öğretiminin bilimin doğasına ilişkin görüşler ve epistemolojik inançlar üzerine etkisi. Doktora tezi, Pamukkale Üniversitesi, Denizli.

Cans1z, M.(2014). The effect of history of science instruction on elementary students' scientific literacy/ Bilim tarihi eğitiminin ortaokul öğrencilerinin fen okuryazarlığına etkisi. Doktora tezi, Orta Doğu Teknik Üniversitesi, Ankara.

Collette, A. T., \& Chiappetta, E. L. (1984). Science Instruction in the Middle and Secondary Schools. The CV Mosby Company, 11830 Westline Industrial Drive, St. Louis.

Creswell, J. W. (2003). Research design: Qualitative, quantitative, and mixed methods approaches (2nd ed.). Thousand Oaks, CA: Sage.

Creswell, J. W. (2013). Research design: Qualitative, quantitative, and mixed methods approaches. Sage publications. 
Çalık, M., \& Sözbilir, M. (2014). Parameters of content analysis. Egitim Ve Bilim-Education And Science, 39(174), 33-38.

Çil, E., \& Çepni, S. (2012). The Effectiveness of the Conceptual Change Approach, Explicit Reflective Approach, and Course Book by the Ministry of Education on the Views of the Nature of Science and Conceptual Change in Light Unit. Educational Sciences: Theory and Practice, 12(2), 1107-1113.

Damak, H. (2013). Bilimin özerkliği ve bilim-devlet ilişkileri. Yüksek Lisans tezi, Uludağ Üniversitesi, Bursa.

Deng, F., Chen, D. T., Tsai, C. C., \& Chai, C. S. (2011). Students' views of the nature of science: A critical review of research. Science Education, 95(6), 961-999.

Deve, F. (2015).Bilim tarihi destekli Işık ünitesinin 7. sınıf öğrencilerinin bilimin doğası anlayışlarına etkisi. Yüksek Lisans tezi, Recep Tayyip Erdoğan Üniversitesi, Rize.

Doğan, H. (2015). Farklı ülkelerden 11 - 13 yaş aralığındaki öğrencilerin bilim ve bilim insanı hakkındaki görüşleri. Yüksek lisans tezi, Akdeniz Üniversitesi, Antalya.

Driver, R., Leach, J., Millar, R., \& Scott, P. (1996). Young people's images of science. McGraw-Hill International.

Durmuş, Z., Ö.(2013).Cumhuriyet dönemi fen eğitimi dokümanlarında bilim konusundaki değişim: Tarihsel yorumlamacı bir içerik analizi. Yüksek Lisans tezi, Marmara Üniversitesi, İstanbul.

Erdaş, E., Doğan, N. \& İrez, S. (2016) Bilimin doğasıyla ilgili 1998-2012 yılları arasında Türkiye'de yapılan çalışmaların değerlendirilmesi. Cilt:24, No:1, Kastamonu Eğitim Dergisi $17-36$

Ertaş, Ö.(2013). Bilim insanlarının ve ilköğretim 2. kademe fen ve teknoloji öğretmenlerinin bilimin doğasına ilişkin görüşlerinin incelenmesi. Yüksek Lisans tezi, Trakya Üniversitesi, Edirne. 
Gül,E.,M.(2014).Doğrudan-yansıtıcı yaklaşım açısından desenlenen iki tamamlayıcı dersin bilimin doğasına ilişkin anlayışlara etkisi. Yüksek Lisans tezi, İnönü Üniversitesi, Malatya.

Gökçek , T., Babacan, F.Z., Kangal, E., Çakır, N.\& Kül , Y. (2013).2003-2012 yı1ları arasında Türkiye'de karma araştırma yöntemiyle yapılan eğitim çalışmalarının analizi. Science. Cilt 6, Say1 7, s. 435-456.

İmer, N.(2013).Fen bilgisi öğretmen adaylarının bilimin doğası anlayışlarının geliştirilmesinde hipermedyanın kullanılması: Öz düzenleme faktörünün incelenmesi. Doktora tezi, Gazi Üniversitesi, Ankara.

İnce,K..\& Özgelen,N.(2015). Bilimin Doğası Alanında Son 10 Yılda Yapılan Çalışmaların Farkl1 Değişkenler Açısından İncelenmesi. Mersin Üniversitesi Eğitim Fakültesi Dergisi, Cilt 11, Sayı 2, s. 447-468.

Karakaya, E.(2015). Bilimsel bilginin doğasını anlama ile sosyo - bilimsel konularda akı1 yürütme. Yüksek Lisans tezi, Marmara Üniversitesi, İstanbul.

Kaya, E.(2015). Birleştirilmiş sınıflı ilkokullarda görev yapan öğretmenlerin teknolojik pedagojik alan bilgisi seviyelerinin belirlenmesi. Yüksek Lisans tezi, Fırat Üniversitesi, Elazı $\breve{g}$.

Korsacılar, S.(2014).9. sınıf fiziğin doğası ünitesindeki temel kavramların öğretiminde yaşam temelli öğretim ve öğrenme istasyonları yönteminin etkililiği. Yüksek Lisans tezi, Dokuz Eylül Üniversitesi, İzmir.

Lederman, N. G. (1992). Students' and teachers' conceptions of the nature of science: A review of the research. Journal of research in science teaching,29(4), 331-359.

Lederman, N. G. (2004). Syntax of nature of science within inquiry and science instruction. in Scientific inquiry and nature of science (pp. 301-317). Springer Netherlands. 
Lederman, N. G. (2007). Nature of sciene: Past, present, and future. In Abell, S. K., \&Lederman, N. G. (Eds.), Handbook of research on science education (pp. 831879).Mahwah, NJ: Lawrence Erlbaum Associates.

Lederman, N. G., \& Zeidler, D. L. (1987). Science teachers' conceptions of the nature of science: Do they really influence teaching behavior?. Science Education, 71(5), 721734.

Leech, N. L., \& Onwuegbuzie, A. J. (2009). A typology of mixed methods research designs. Quality and Quantity, 43, 265-275.

Milli Eğitim Bakanlığı Talim Terbiye Kurulu Başkanlığı, (2005) İlköğretim 6.-8. Sınıflar Fen ve Teknoloji Dersi Öğretim Programı. Ankara: MEB Yayınları

Milli Eğitim Bakanlığı Talim Terbiye Kurulu Başkanlığı, (2013). İlköğretim Kurumları Fen Bilimleri Dersi (3, 4, 5, 6, 7 ve 8. Sinıflar) Öğretim Programı, Ankara: Devlet Kitapları Müdürlüğü.

National Research Council (NRC). (1996). National science education standards. Washington, DC: The National Academy Press.

NGSS Lead States. (2013). Next generation science standards: For states, by states. Washington, DC: The National Academy Press.

Norris, S. P., \& Phillips, L. M. (2003). How literacy in its fundamental sense is central to scientific literacy. Science education, 87(2), 224-240.

Ornstein, A. C. and Hunkins, F. P.(1993). Curriculum: Foundations, Principles, Theory. 2nd ed. Boston: Allyn and Bacon.

Özbek, D. (2013). Fen teknoloji toplum dersi kapsamında yapılan uygulamaların öğretmen adaylarının bilimin doğasının unsurlarını algılama düzeylerindeki değişime etkisi. Yüksek Lisans tezi, Karadeniz Teknik Üniversitesi, Trabzon. 
Özcan, H. (2013). Fen bilgisi öğretmen adaylarının fen içeriği ile ilişkilendirilmiş bilimin doğası konusundaki pedagojik alan bilgilerinin gelişimi. Doktora tezi, Gazi Üniversitesi, Ankara.

Quigley, C., Pongsanon, K. ve Akerson, V.,L. ( 2011). If we teach them, they can learn: Young students views of nature of science during an informal science education program. Journal of Science Teacher Education. March 2011, Volume 22, Issue 2, pp 129- 149.

Salgar, E. (2015). Doğa bilimlerinde ilerleme kavramının pozitivist ve post-pozitivist düşüncelerdeki yeri üzerine bir araştırma. Doktora tezi, Ankara Üniversitesi, Ankara.

Seçkin, M. (2013). Fen ve teknoloji dersinde belgesel kullanılmasının 8. sınıf öğrencilerinin hücre ile kuvvet konularındaki başarılarına ve bilimin doğası hakkındaki görüşlerine etkisi. Doktora tezi, Hacettepe Üniversitesi, Ankara.

Soğuksu, Y. (2013). Biyoloji öğretmen adaylarının biyolojik okuryazarlı̆̆ının değerlendirilmesi. Yüksek Lisans tezi, Necmettin Erbakan Üniversitesi,Konya.

Sönmez, E.(2014). Müfredat dişı biyoteknoloji etkinliklerinin öğrencilerin biyoteknoloji bilgilerine ve bilimin doğası hakkındaki görüşlerine etkisi. Yüksek Lisans tezi, Kastamonu Üniversitesi, Kastamonu.

Suri, H., \& Clarke, D. (2009). Advancements in research synthesis methods: From a methodologically inclusive perspective. Review of Educational Research, 79(1), 395430.

Şen,M.(2014).A study on science teachers' pedagogical content knowledge and content knowledge regarding cell division. Yüksek Lisans tezi, Orta Doğu Teknik Üniversitesi, Ankara. 
Tashakkori, A., \& Teddlie, C. (1998). Mixed methodology: Combining qualitative and quantitative approaches. Applied Social Research Methods Series (Vol.46.). Thousand Oaks, CA: Sage

Tashakkori, A., \& Teddlie, C. (Eds). (2003). Handbook of mixed methods in social and behavioral research. Thousand Oaks, CA: Sage.

Tortumlu,S.(2014). Bilimin doğasının lise kimya ders kitaplarında ele alınışı. Yüksek Lisans tezi, Yüzüncü Y1l Üniversitesi, Van.

Tunç, C. (2013).Sosyal bilgiler öğretmen adaylarının bilimsel okuryazarlıklarının geliştirilmesi: 'Bilim Teknoloji Sosyal Değişme' dersinin eylem araştırması ile tasarlanmas1. Doktora tezi, Marmara Üniversitesi, İstanbul.

Tungaç, A.(2015). Fen bilgisi öğretmenlerinin okul dışı (Doğa deneyimine bağl1) çevre eğitimine yönelik özyeterlik algıları, çevresel tutumları ve çevre bilgilerinin incelenmesi: Mersin ili örneği. Yüksek Lisans tezi, Mersin Üniversitesi, Mersin.

Türkaslan, M. (2014).Sınıf öğretmen adaylarının bilimin doğasına yönelik görüşlerinin incelenmesi. Yüksek Lisans tezi Zirve Üniversitesi, Gaziantep.

Türköz, G. (2015). Bilimin doğası etkinliklerinin öğrencilerin kavramsal anlama, bilimsel süreç becerileri ve bilimin doğası anlayışlarına etkisi. Yüksek Lisans tezi, Pamukkale Üniversitesi, Denizli.

Ünal, S., Çoştu, B., Karataş, F.,Ö. (2004) Türkiye'de fen bilimleri eğitimi alanındaki program geliştirme çalışmalarına genel bir bakış. Gazi Eğitim Fakültesi Dergisi, Cilt 24, Sayı $2,183-202$

Yener, S. (2013).Biyoloji öğretim programı ile biyoloji öğretmen adaylarının bilim ve bilimin doğasına yönelik bakış açılarının değerlendirilmesi. Yüksek Lisans tezi, Necmettin Erbakan Üniversitesi, Konya. 
YYÜ Ĕ̆itim Fakültesi Dergisi (YYU Journal Of EducationFaculty),2017; 14(1):1178-1218, http://efdergi.yyu.edu.tr

ISSN:1305-020

Yıldırım, A. \& Şimşek, H., (2011). Sosyal bilimlerde nitel araştırma yöntemleri. Seçkin Yayıncılık, Ankara.

Yücedağ, M. (2015). Kavram karikatürleriyle zenginleştirilmiş etkileşimli kısa tarihsel hikâyelerin bilimin doğası öğretiminde kullanımı üzerine bir öz-inceleme. Doktora tezi, Gazi Üniversitesi, Ankara.

Weld, J. (2004). The game of science education. Pearson Education.

Wiles, J., Bondi, J. (1989). Curriculum Development: A Guide to Practice. Merrill Pub. Co. 